Prepared in cooperation with the

ARIZONA DEPARTMENT OF WATER RESOURCES and the

U.S. GEOLOGICAL SURVEY

GROUND-WATER RESOURCES PROGRAM

\title{
Simulated Water-Level Responses, Ground-Water Fluxes, and Storage Changes for Recharge Scenarios along Rillito Creek, Tucson, Arizona
}

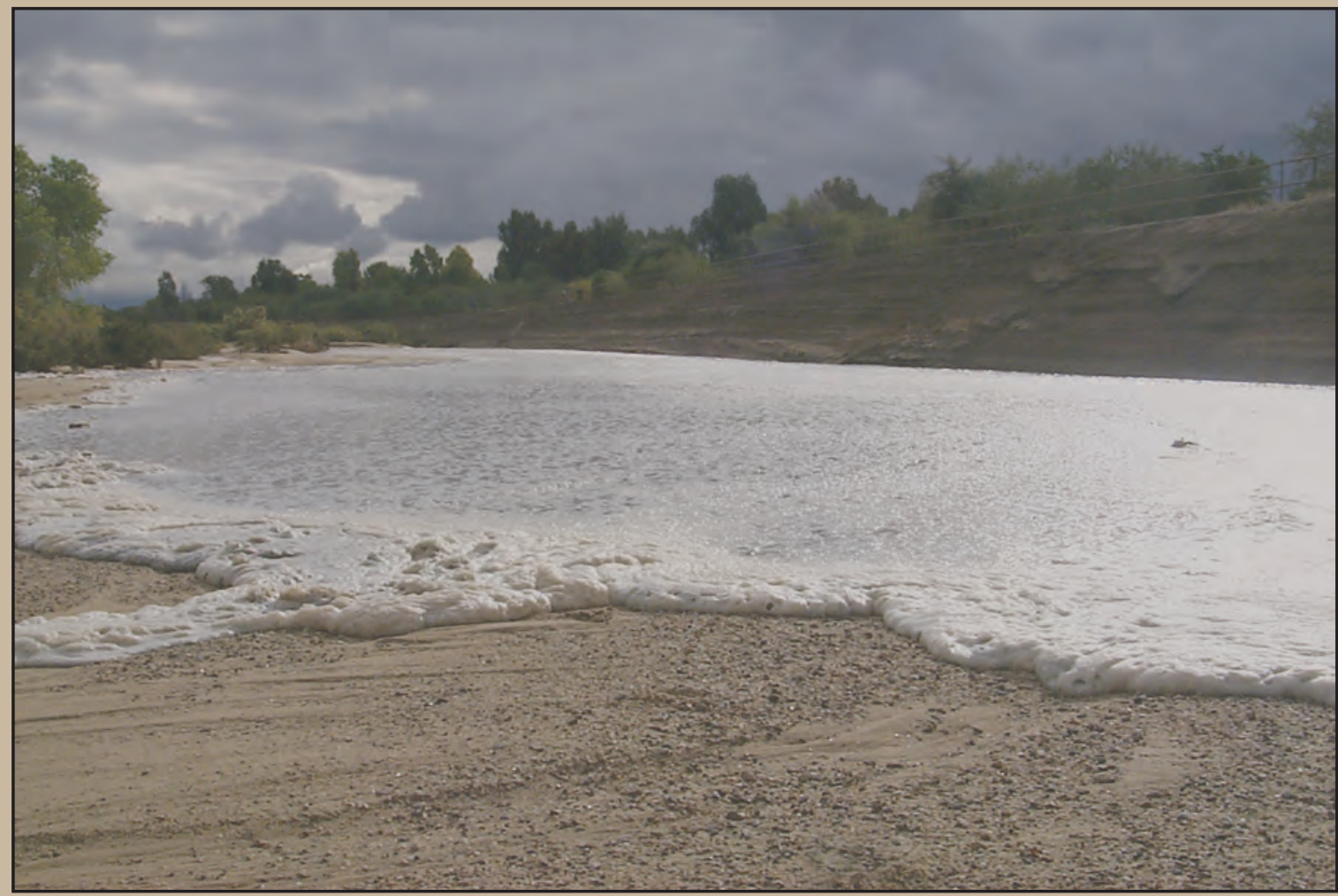

Scientific Investigations Report 2004-5286

U.S. Department of the Interior

U.S. Geological Survey

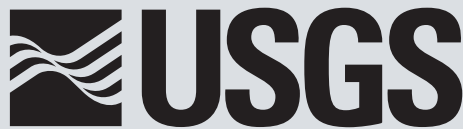

science for a changing world 
This page left blank intentionally. 


\section{Simulated Water-Level Responses, Ground-Water Fluxes, and Storage Changes for Recharge Scenarios along Rillito Creek, Tucson, Arizona}

By John P. Hoffmann and S.A. Leake

Prepared in cooperation with the ARIZONA DEPARTMENT OF WATER RESOURCES and the U.S. GEOLOGICAL SURVEY GROUND-WATER RESOURCES PROGRAM

Scientific Investigations Report 2004-5286 


\title{
U.S. Department of the Interior \\ Gale A. Norton, Secretary \\ U.S. Geological Survey \\ Charles G. Groat, Director
}

\author{
U.S. Geological Survey, Reston, Virginia: 2005 \\ For sale by U.S. Geological Survey, Information Services \\ Box 25286, Denver Federal Center \\ Denver, CO 80225 \\ Prepared by the Arizona Water Science Center, Tucson \\ For more information about the USGS and its products: \\ Telephone: 1-888-ASK-USGS \\ World Wide Web: http://www.usgs.gov/ \\ Any use of trade, product, or firm names in this publication is for descriptive purposes only and does not imply \\ endorsement by the U.S. Government.
}

Although this report is in the public domain, permission must be secured from the individual copyright owners to reproduce any copyrighted materials contained within this report.

\section{Suggested citation:}

Hoffmann, J.P., and Leake, S.A., 2005, Simulated water-level responses, ground-water fluxes, and storage changes for recharge scenarios along Rillito Creek, Tucson, Arizona: U.S. Geological Survey Scientific Investigations Report 2004-5286, 29 p. 


\section{Contents}

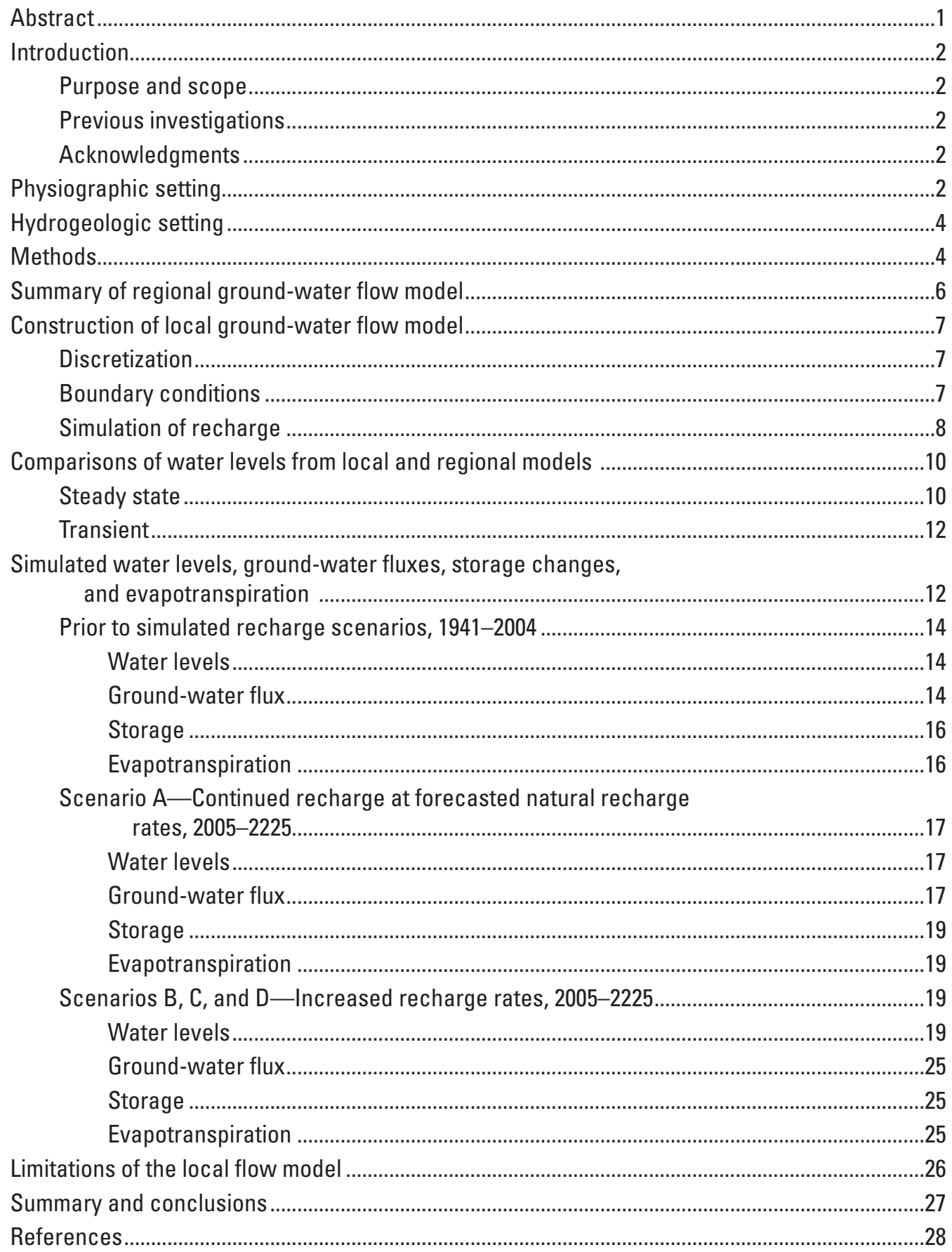




\section{Figures}

1. Map showing areas of regional and local ground-water flow models, Arizona ...........3

2. Map showing area of local model, location of line segments, selected cells used for hydrographs, and the approximate water-level drawdown in the vicinity of the Central Well Field, Tucson, Arizona, between 1945 and 1995.

3. Graphs showing difference in the distribution of recharge applied to the steady-state local model between the Recharge and Stream Packages, Rillito Creek, Arizona

4. Map showing simulated water-level altitude in layer 2 of the local model using the Recharge and Stream Packages along Rillito Creek, Tucson, Arizona.

A. Water-level altitude for steady-state simulations, 1940 .9

B. Water-level altitude for transient simulations, 1999 .

5. Graph showing recharge to model cells coinciding with Rillito Creek, Tucson, Arizona, 1941-2025

6. Map showing simulated water-level altitudes in layer 2 for regional and local models using the Stream Package along Rillito Creek, Tucson, Arizona.

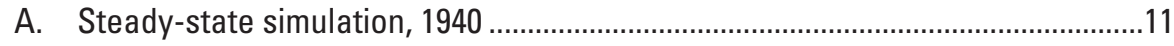

B. Transient simulation, 1999

7. Hydrographs for selected local-model cells near Rillito Creek and the Central Well Field for model layers 1, 2, and 3, Tucson, Arizona, 1941-99.

8. Hydrograph for selected cells 28,38 , layer 2 , in the local and regional models, 1941-99, Rillito Creek, Arizona

9. Graph showing amount of streambed recharge applied to the local model using the Stream Package along Rillito Creek, Arizona, and pumpage for each scenario

10. Simulated hydrographs for selected cells in the local model, Rillito Creek, Arizona, 1941-2004

11-14. Graphs showing:

11. Simulated annual ground-water flux past line segment 1 in the local model, Rillito Creek, Arizona, 1941-2225.

12. Simulated annual ground-water flux past line segment 2 in the local model, Rillito Creek, Arizona, 1941-2225.

13. Simulated annual change in ground-water storage in the local model, Rillito Creek, Arizona, 1941-2225.

14. Simulated annual loss of ground water due to evapotranspiration in the local model, Rillito Creek, Arizona, 1941-2225

15. Hydrographs for selected cells in the local model, Rillito Creek,

Arizona, 2005-2225

16. Maps showing water-level altitude for scenario $A$ in the local model for selected times, Rillito Creek, Arizona.
A. 2004
B. 2015
C. 2025
D. 2050 . .18
E. 2100 ...18
F. 2225 .18 


\section{Figures-Continued}

17. Graphs showing water-level altitude for each scenario for cells in the local model, 1940-2225, Rillito Creek, Arizona.
A. Scenario B
B. Scenario C
. .20
C. Scenario D

18. Graphs showing rise in water level for each scenario relative to scenario $\mathrm{A}$ for selected cells in the local model, 2000-2225, Rillito Creek, Arizona.
A. Scenario B
B. Scenario C
C. Scenario D

19-21. Maps showing:

19. Rises in water level for scenario $B$ relative to scenario $A$ within the local model for selected times, Rillito Creek, Arizona.
A. 2015 .22
B. 2025
. .22
C. 2050
.22
D. 2100 . .22
E. 2150 . .22
F. 2225

20. Rises in water level for scenario $C$ relative to scenario $A$ within the local model for selected times, Rillito Creek, Arizona.
A. 2015 . .23
B. 2025
. .23
C. 2050
.23
D. 2100
E. 2150
F. 2225

21. Rises in water level for scenario $D$ relative to scenario $A$ within the local model for selected times, Rillito Creek, Arizona.
A. 2015 .24
B. 2025 .24
C. 2050 . .24
D. 2100 . .24
E. 2150 .24
F. 2225 


\section{Tables}

1. Water-budget components in the Arizona Department of Water Resources's calibrated regional ground-water flow model of the Tucson Active Management Area for steady-state simulations in 1940

2. Evapotranspiration within local ground-water flow model for various scenarios, Rillito Creek, Arizona

\section{Conversion Factors and Datum}

\begin{tabular}{lcl}
\hline Multiply & By & To obtain \\
\hline \multicolumn{1}{l}{ foot $(\mathrm{ft})$} & Length & \\
mile $(\mathrm{mi})$ & 0.3048 & meter $(\mathrm{m})$ \\
\hline & 1.609 & kilometer $(\mathrm{km})$ \\
\hline square mile $\left(\mathrm{mi}^{2}\right)$ & Area & \\
acre-foot $(\mathrm{acre}-\mathrm{ft})$ & 2.59 & square kilometers $\left(\mathrm{km}^{2}\right)$ \\
\hline & 1,233 & cubic meter $\left(\mathrm{m}^{3}\right)$ \\
\hline acre-foot per year $(\mathrm{acre}-\mathrm{ft} / \mathrm{yr})$ & Flow rate & \\
cubic foot per second $(\mathrm{ft} 3 / \mathrm{s})$ & 1,233 & cubic meter per year $\left(\mathrm{m}^{3} / \mathrm{yr}\right)$ \\
\end{tabular}

Temperature in degrees Fahrenheit $\left({ }^{\circ} \mathrm{F}\right)$ may be converted to degrees Celsius $\left({ }^{\circ} \mathrm{C}\right)$ as follows:

$$
{ }^{\circ} \mathrm{C}=\left({ }^{\circ} \mathrm{F}-32\right) / 1.8
$$

Vertical coordinate information is referenced to the National Geodetic Vertical Datum of 1929 (NGVD of 1929); horizontal coordinate information is referenced to the North American Datum of 1927 (NAD27). Altitude, as used in this report, refers to distance above or below NGVD of 1929. 


\title{
Simulated Water-Level Responses, Ground-Water Fluxes, and Storage Changes for Recharge Scenarios along Rillito Creek, Tucson, Arizona
}

\author{
By John P. Hoffmann and S.A. Leake
}

\section{Abstract}

A local ground-water flow model is used to simulate four recharge scenarios along Rillito Creek in northern Tucson to evaluate mitigating effects on ground-water deficits and water-level declines in Tucson's Central Well Field. The local model, which derives boundary conditions from a basin-scale model, spans the 12-mile reach of Rillito Creek and extends 9 miles south into the Central Well Field. Recharge scenarios along Rillito Creek range from 5,000 to 60,000 acre-feet per year and are simulated to begin in 2005 and extend through 2225 to estimate long-term changes in ground-water level, ground-water storage, ground-water flux, and evapotranspiration.

The base case for comparison of simulated water levels and flows, referred to as scenario A, uses a long-term recharge rate of 5,000 acre-feet per year to 2225. Scenario B, which increases the recharge along Rillito Creek by 9,500 acre-feet per year, has simulated water-level rises beneath Rillito Creek that range from about 53 feet to 86 feet. Water-level rises within the Central Well Field range from about 60 feet to 80 feet. More than half of these rises occur by 2050, and more than 95 percent occur by 2188. Scenario C, which increases the recharge along Rillito Creek by 16,700 acre-feet per year relative to scenario A, has simulated water-level rises beneath Rillito Creek that range from about 71 feet to 102 feet. Water-level rises within the Central Well Field range from about 80 feet to 95 feet. More than half of the rises occur by 2036, and more than 95 percent occur by 2100. Scenario D, which initially increases the recharge rate by about 55,000 acre-feet per year relative to scenario A, resulted in simulated water levels that rise to land surface along Rillito Creek. This rise in water level resulted in rejected recharge. As the water table continued to rise, the area of stream-channel surface intersected by the water table increased causing continual decline in the recharge rate until a long-term recharge rate of about 34,000 acre-feet per year was sustained. The long-term recharge rate for scenario D is about 29,000 acre-feet per year greater than the long-term recharge rate for scenario A. Simulated long-term water-level rises beneath Rillito Creek range from about 97 feet to 131 feet, resulting in water levels near or at the land surface. Shallow depths to water associated with this scenario have implications for contamination owing to the presence of landfills within or adjacent to Rillito Creek. Water-level rises for cells within the Central Well Field range from about 96 feet to 109 feet. More than half of the water-level rises occur by 2018 and more than 95 percent occur by 2041 .

Almost all the increased water added to the ground-water system in the recharge scenarios can be accounted for by a combination of increased storage near Rillito Creek, ground-water flux to the south, ground-water flux to the northwest, and increased discharge as evapotranspiration along Rillito Creek. The percentage of newly added water accounted for by storage changes is large relative to the percentage accounted for by changes in flux and evapotranspiration at the onset of each scenario; however, the changes in storage become smaller throughout the simulation, and the long-term component accounted for by storage is minimal. Long-term ground-water fluxes to the south increase by about 3,300, 4,840, and 7,500 acre-feet per year for scenarios B, C, and D, respectively. The percentage of increased recharge that flows south toward the Central Well Field, therefore, is 35,29 , and 26 percent for scenarios $\mathrm{B}, \mathrm{C}$, and $\mathrm{D}$, respectively. Long-term ground-water fluxes to the northwest increase by about 3,100, 3,900, and 6,980 acre-feet per year for scenarios B, C, and D, respectively. The long-term percentage of increased recharge flowing northwestward is about 31,25, and 21 percent for scenarios B, C, and D, respectively. Shallow ground-water evapotranspiration along Rillito Creek increases by about 310, 4,100, and 12,000 acre-feet per year for scenarios B, C, and D, respectively. The losses owing to evapotranspiration account for about 3, 25, and 41 percent of the added recharge for scenarios $\mathrm{B}, \mathrm{C}$, and D, respectively. 


\section{Introduction}

The city of Tucson and surrounding areas (fig. 1) obtain most of their municipal, agricultural, and industrial water from ground water that is withdrawn from thick alluvial aquifers underlying the desert basins. A large fraction of ground water stored in these aquifers was recharged by water that percolated through ephemeral stream-channel deposits (Matlock and Davis, 1972; Davidson, 1973; Hanson and Benedict, 1994). The amount of water that recharges the aquifers is insufficient to meet current and expected future demands. The projected resultant ground-water deficit, which is expected to grow as the population increases, is manifested in water-level declines of more than $200 \mathrm{ft}$ since the middle of the twentieth century. These projected declines are largest in the Central Well Field where ground-water withdrawals are greatest. To help mitigate the deficit and associated water-level declines, an in-stream recharge facility has been proposed for the Rillito Creek channel. Rillito Creek is an ephemeral stream in the northern part of Tucson. A possible source of water for artificial recharge is Colorado River water that is transported from Lake Havasu and delivered to the Tucson area through the Central Arizona Project (CAP) canal. In 1999, the U.S. Geological Survey (USGS), in cooperation with the Arizona Department of Water Resources (ADWR), began an investigation to evaluate the physical characteristics of the shallow subsurface sediments beneath Rillito Creek that can influence recharge processes. Information from this investigation, combined with ADWR's calibrated regional ground-water flow model of the Tucson Active Management Area (TAMA), which includes the Upper Santa Cruz Basin and Avra Valley (Dale Mason, hydrologist, Arizona Department of Water Resources, written commun., 2003), is used to simulate various recharge scenarios along Rillito Creek. These simulations are used to evaluate mitigating effects on ground-water deficits and water-level declines for various recharge scenarios.

\section{Purpose and Scope}

The purpose of this report is to describe numerical simulations used to estimate possible responses of groundwater level, ground-water flux, and selected water-budget terms to four recharge scenarios along Rillito Creek. Recharge scenarios along Rillito Creek were developed on the basis of consultation between the USGS and the ADWR and are simulated to begin in 2005 by using ADWR's calibrated model input data sets that extend to 2025 . The predictive simulations are based on ADWR's estimate of groundwater withdrawal amounts and locations, and assume a constant long-term natural recharge rate along Rillito Creek
(Dale Mason, hydrologist, Arizona Department of Water Resources, written commun., 2003). To estimate the longterm responses of water level, ground-water flux, and selected water-budget components, four recharge scenarios are simulated by extending the 2025 input data sets to 2225 . The responses for three scenarios are compared to a base case scenario. The numerical model used to simulate the four recharge scenarios was created by embedding a local groundwater flow model within the calibrated ADWR regional transient ground-water flow model (TAMA model). The local model spans the 12-mi reach of Rillito Creek and extends $9 \mathrm{mi}$ south into Tucson's Central Well Field. In this report, waterlevel altitudes for model layer 2 are shown for all comparisons because layer 1 becomes unsaturated in parts of the model during the transient simulation.

\section{Previous Investigations}

Investigations conducted within the Rillito Creek area include geologic and hydrogeologic analyses and numerical ground-water modeling. Pashley (1966), Davidson (1973), and Anderson (1987) documented the geology and stratigraphy of the area. Hoffmann and others (2002) characterized the shallow deposits beneath Rillito Creek. Burkham (1970), Davidson (1973), and Anderson and others (1990) described the hydrogeology and water resources of the area. Anderson (1972), Hanson and Benedict (1994), and Travers and Mock (1984) developed ground-water flow models of the area. These models are of regional scale and do not specifically focus on effects of varying recharge along Rillito Creek.

\section{Acknowledgments}

Dale Mason and Lou Bota of ADWR's Hydrology Section provided input data sets for the TAMA model. Matthew Weber and Denise Weiland of the TAMA ADWR office were instrumental in providing guidance on recharge-scenario selection and served as liaisons between the ADWR's Hydrology Section and the USGS.

\section{Physiographic Setting}

Rillito Creek is in the northern part of the Upper Santa Cruz Basin and drains an area of about $900 \mathrm{mi}^{2}$ (fig. 1). The Upper Santa Cruz Basin is a north-south trending alluvial basin that is generally bounded by block-faulted mountains. The basin contains the Tucson metropolitan area, which is the major urban population center in southeastern Arizona. The Avra Valley Basin is west of the Upper Santa Cruz Basin and is in hydraulic connection with the Upper Santa Cruz Basin in the northwestern part of the study area near Marana, Arizona. 


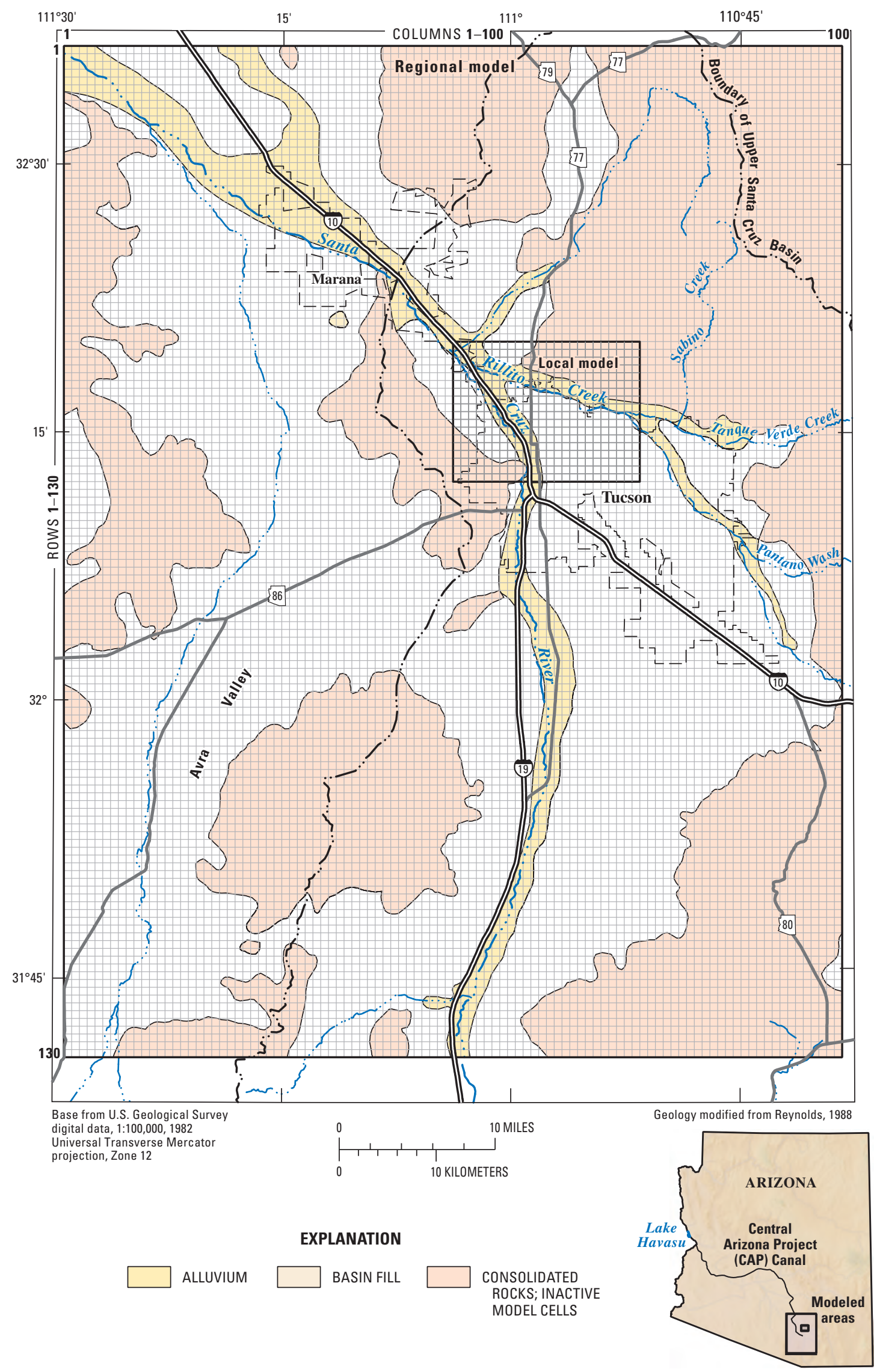

Figure 1. Areas of regional and local ground-water flow models, Arizona. 
The climate of the Upper Santa Cruz Basin is semiarid; rainfall ranges from 11 to 16 in. on the valley floor to as much as 30 in. in the surrounding mountains. In January, the mean daily maximum temperature is $75^{\circ} \mathrm{F}$ and the mean daily minimum is $50^{\circ} \mathrm{F}$. In July, the mean daily maximum temperature is $105^{\circ} \mathrm{F}$ and the mean daily minimum is $83^{\circ} \mathrm{F}$.

\section{Hydrogeologic Setting}

The Upper Santa Cruz Basin is in the Basin and Range Physiographic Province, which is characterized by blockfaulted mountains separated by basins filled with alluvial sediments (Fenneman, 1931). The block-faulted mountains comprise Precambrian through Tertiary granitic, metamorphic, volcanic, and consolidated sedimentary rock. The sediments that fill the basins are collectively termed alluvial basin-fill deposits and consist of gravel, sand, silt, clay, and minor amounts of anhydrous evaporate sediments of Tertiary to Quaternary age. The basin-fill deposits are generally coarse grained along the basin margins and grade into finer-grained deposits and anhydrous evaporites in the central parts of the basins. The basin-fill deposits form regionally extensive sedimentary units that form the regional aquifer system.

Rillito Creek and much of the Upper Santa Cruz Basin are underlain by thick basin-fill deposits that store the groundwater resources for the Tucson metropolitan area. Recharge to the basin-fill aquifer is less than the amount of groundwater withdrawal needed to support the growing metropolitan population (Water Resources Research Center, 1999). As a result of these ground-water withdrawals, water levels have declined over the long term, causing land subsidence in some areas. Rivers and washes that drain the basin are generally ephemeral, only flowing in response to local rainfall. Major tributaries to Rillito Creek are Tanque Verde Creek, Pantano Wash, and Sabino Creek (fig. 1).

Previous investigators have divided the basin-fill deposits into an upper basin-fill unit and a lower basin-fill unit on the basis of general hydrogeologic characteristics (Pool, 1985; Hanson and Benedict, 1994). The upper basin-fill unit ranges in thickness from several hundred feet to as much as $1,000 \mathrm{ft}$. The unit consists mostly of semiconsolidated to unconsolidated gravel, sands, and clayey silt, and is correlated to the upper Tinaja beds and the Fort Lowell Formation described by Anderson $(1987,1988)$. The lower basin-fill unit is several thousands of feet thick and consists of conglomerates, gravels, sands, silts, anhydritic clayey silts, and mudstones (Anderson, 1988). The unit is equivalent to the Pantano Formation and the lower and middle Tinaja beds described by Anderson (1987, 1988). Thickness of the basin fill ranges from a veneer along the mountain fronts to as much as 11,200 ft in the Upper Santa Cruz Basin (Davidson, 1973; Anderson, 1987, 1988; Hanson and Benedict, 1994).
Depth to ground water in the basin-fill deposits beneath and surrounding Rillito Creek varies from less than $20 \mathrm{ft}$ in the upper reaches of Rillito Creek, to more than $350 \mathrm{ft}$ in the Central Well Field south of Rillito Creek (Tucson Water, 2000, plate 1; Hoffmann and others, 2002). Depth to ground water immediately beneath Rillito Creek generally ranges from less than $20 \mathrm{ft}$ in the upper reach to $150 \mathrm{ft}$ in the middle and lower reaches (Hoffmann and others, 2002). Flow of ground water is generally northwestward, and water-table altitudes are about 2,500 ft in the southeastern part of the study area and 2,100 ft in the northwestern part. Ground water along the upper reach of Rillito Creek locally flows southwestward toward the Central Well Field, and ground water along the middle and lower reaches locally flows northwestward (Tucson Water, 2000, plate 2).

The mountains surrounding the Upper Santa Cruz Basin comprise Precambrian to Tertiary-aged crystalline and sedimentary rocks that generally yield little water and are not considered part of the regional aquifer.

\section{Methods}

A calibrated regional ground-water flow (TAMA) model (Dale Mason, hydrologist, Arizona Department of Water Resources, written commun., 2003) was used to provide boundary conditions for a local flow model centered approximately over Rillito Creek and the Central Well Field. The telescoping mesh-refinement program, MODTMR, was used to create ground-water flow model input data sets for MODFLOW, which is the Modular Three-Dimensional Finite Difference Ground-Water Flow Model (MODFLOW96) developed by the USGS (McDonald and Harbaugh, 1988; McDonald and Harbaugh, 1996). The TAMA model is used to define boundary conditions and model parameters for the smaller local model (Leake and Claar, 1999). Output from the TAMA model was used to construct the data sets that specify boundary conditions on the perimeter of the local model. The method is used where a detailed model is needed for an area that is small relative to the entire aquifer system or the regional model. In this case, the local model covers an area of $108 \mathrm{mi}^{2}$ centered approximately over Rillito Creek (fig. 2), and the TAMA model has an area of 3,250 $\mathrm{mi}^{2}$ (fig. 1).

The purpose of this investigation was to evaluate recharge scenarios related to the introduction of CAP water to Rillito Creek; therefore, it was necessary to simulate recharge along Rillito Creek by using the Stream Package for MODFLOW (Prudic, 1989). In the TAMA model, however, recharge is applied through the Recharge Package (McDonald and Harbaugh, 1988). The TAMA model was adapted for this investigation by removing specified recharge and adding the Stream Package along cells that coincide with Rillito Creek. 


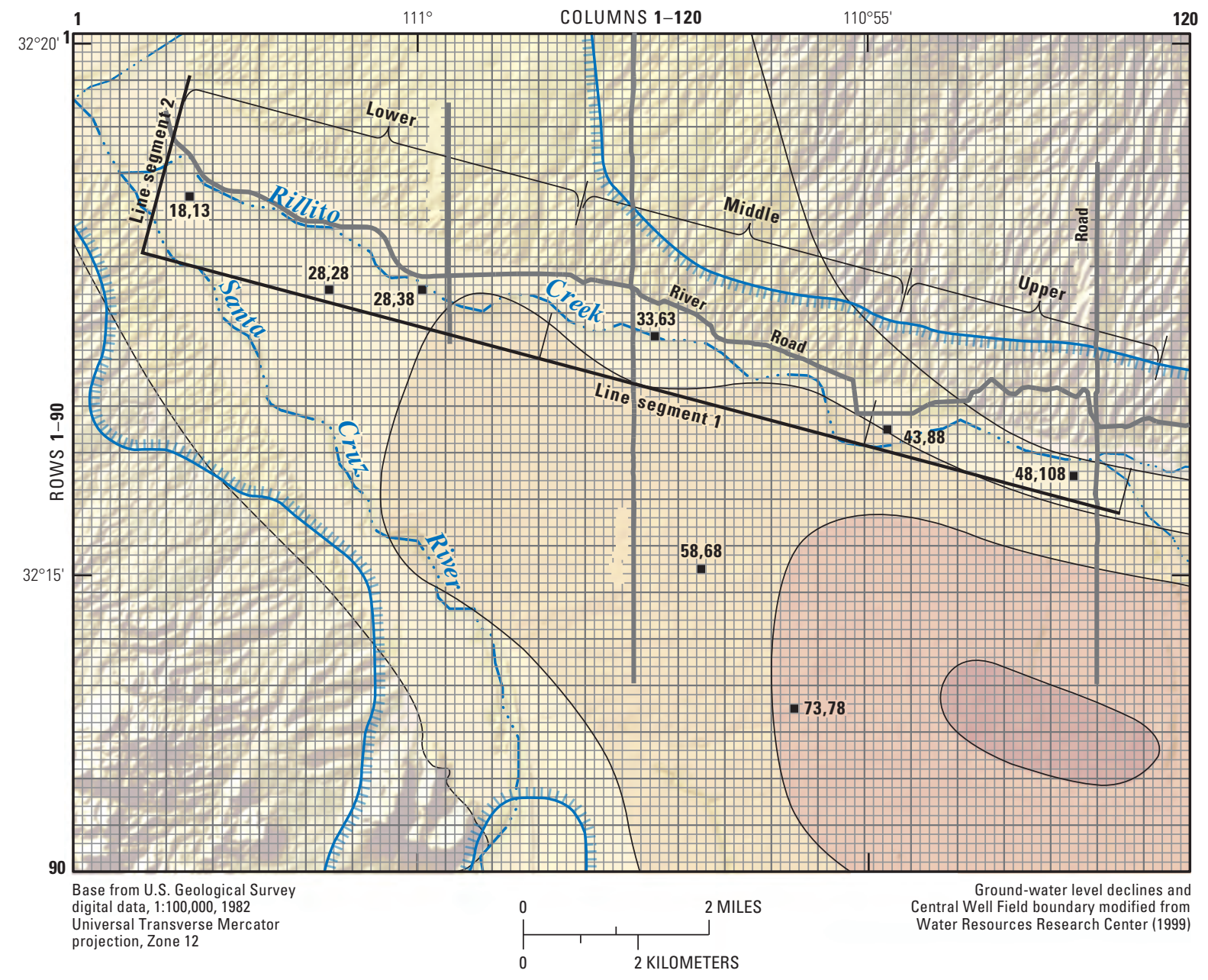

EXPLANATION

NOTE: See fig. 10 for projected hydrographs for selected cells and figs. 17 and 18 for projected water-level APPROXIMATE DECLINE IN GROUND-WATER LEVELS FROM 1940 TO 1995, IN FEET:

\begin{tabular}{lll}
$\square$ & 50 TO 100 & \\
$\square$ & 150 TO 200 \\
\hline & 100 T0 150 & GREATER THAN 200
\end{tabular}

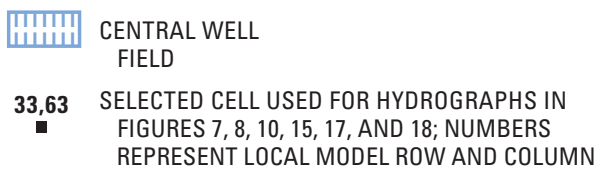

Figure 2. Area of local model, location of line segments, selected cells used for hydrographs, and the approximate water-level drawdown in the vicinity of the Central Well Field, Tucson, Arizona, between 1945 and 1995.

Applying recharge by using the Stream Package has advantages over applying recharge by using the Recharge Package because recharge in the Stream Package is calculated on the basis of head differences between the stream and the aquifer and a streambed-conductance term. Using the Stream Package allows a variety of recharge scenarios to be evaluated by using different streamflow values along Rillito Creek. Streamflow values used in the recharge scenarios range from $5,000 \mathrm{acre}-\mathrm{ft} / \mathrm{yr}$, a long-term average natural recharge rate used in the TAMA model for cells underlying Rillito Creek, to 60,000 acre-ft/yr, an amount of CAP water potentially available for artificial recharge along Rillito Creek. When the Stream Package is used, recharge to the aquifer is ceased when all streamflow has leaked into the aquifer and the stream is dry, or when the water table reaches the land surface and additional recharge is rejected.

The computer code RIVGRID (Leake and Claar, 1999) was used to create the MODFLOW input data sets for the Stream Package. RIVGRID is a program that uses the coordinates of stream paths and information such as altitude, width, and streambed hydraulic conductivity, thickness, and roughness to estimate streambed-conductance terms. Streambed altitudes were obtained from orthophotoquads having 2-ft contour intervals; streambed widths were estimated on the 
basis of field measurements; streambed hydraulic conductivity values were varied on the basis of findings of Hoffmann and others (2002); and streambed roughness values were varied on the basis of literature citations (White, 1979).

Steady-state and transient simulations were run on the TAMA and local models. The computer code TMRDIFF (Leake and Claar, 1999) was used to compare simulated waterlevel altitude in the local model with simulated water-level altitude in the regional model. Each recharge scenario was simulated within the TAMA model to provide flow conditions at the perimeter of the local model. Results from the local-model recharge scenarios were used to analyze spatial and temporal changes in water level, ground-water flux, and selected water-budget terms.

The local model was first used to predict aquifer response up to 2025 for different recharge scenarios that take place starting in 2005. Selection of 2005 to begin varying the recharge for respective scenarios was arbitrary. The characteristics and boundary conditions for the local model were derived from the TAMA model. Hydrologic data from 1940 to 1999 were used to calibrate the TAMA model; therefore, application of the local model for studies of system responses resulting from various recharge scenarios can be considered to be predictive up to the year 2025. This study further uses the local model to compute responses for an additional 200 years, ending in 2225. Predictions for this additional 200-year period probably are not as reliable as the predictions for the period prior to 2025 because of the amount of data used to calibrate the model. The longer-term analysis, therefore, is considered to be an interpretive model application. Interpretive models are used to evaluate the possible long-term responses on the basis of the most complete information on the system currently available.

\section{Summary of Regional Ground-Water Flow Model}

The code used to simulate regional ground-water flow in the ADWR's TAMA model is the Modular Three-Dimensional Finite Difference Ground-Water Flow Model (MODFLOW96) developed by the USGS (McDonald and Harbaugh, 1988; McDonald and Harbaugh, 1996). The TAMA model study area is 3,250 $\mathrm{mi}^{2}$ and includes portions of the Upper Santa Cruz Basin and Avra Valley (fig. 1). The TAMA model is divided into a regular orthogonal grid, consisting of 130 rows and 100 columns, that is oriented north-south and is 50 mi east to west and $65 \mathrm{mi}$ north to south. Each cell is $0.5 \mathrm{mi}$ on a side.

The model simulates steady-state conditions in 1940 and transient conditions from 1941 to 2000. It is assumed that there was a balance between inflow to the aquifer and outflow from the aquifer before 1940. About 91,000 acre-ft/yr flows through the regional ground-water system under the steady-state conditions of 1940 on the basis of water-budget components for the TAMA model (Dale Mason, hydrologist, Arizona Department of Water Resources, written commun., 2003; table 1).

Table 1. Water-budget components in the Arizona Department of Water Resources's calibrated regional ground-water flow model of the Tucson Active Management Area for steady-state simulations in 1940

\begin{tabular}{lcc}
\hline \multicolumn{1}{c}{ Budget component } & $\begin{array}{c}\text { Inflow, } \\
\text { in acre-feet } \\
\text { per year }\end{array}$ & $\begin{array}{c}\text { Outflow, } \\
\text { in acre-feet } \\
\text { per year }\end{array}$ \\
\hline Mountain-front recharge & 33,670 & \\
Stream infiltration & 38,875 & \\
Ground-water underflow & 18,485 & 19,930 \\
Evapotranspiration & & 11,550 \\
Pumpage & & 59,555 \\
Total & $\mathbf{9 1 , 0 3 0}$ & $\mathbf{9 1 , 0 3 5}$ \\
\hline
\end{tabular}

Although there was ground-water development in the early 1900s, the balance between inflows and outflows probably was maintained by a loss of evapotranspiration (ET) from the riparian areas approximately equal to the amount of pumpage. The MODFLOW ET Package (McDonald and Harbaugh, 1988) is used to simulate ground-water discharge through transpiring phreatophytes or direct evaporation at the land surface. It simulates ET by removing ground water at specified cells at a specified rate depending on the depth to ground water. The ET rate is maximized when the water table is at the land surface; the rate is reduced linearly with depth and ceases when the water table exceeds a specified depth termed the extinction depth. The TAMA model uses an extinction depth of $25 \mathrm{ft}$ at cells simulating ET, which predominantly occurs along the Santa Cruz River, Rillito Creek, and the tributaries of these channels. An ET value of $11,550 \mathrm{acre}-\mathrm{ft} / \mathrm{yr}$ is used in the model for the steady-state period. The ET rate was determined on the basis of vegetation type and density determined from aerial photos taken in 1936 and 1941, and from model calibration (Hanson and Benedict, 1994; Dale Mason, hydrologist, Arizona Department of Water Resources, written commun., 2003). Results from updated TAMA model simulations by the ADWR were provided following the completion of this study. The updated model has refined cell-centered altitudes based on 10-m digital elevation model coverages. These refined altitudes resulted in a total steady-state ET rate of 13,820 acre-ft/yr (Dale Mason, hydrologist, Arizona Department of Water Resources, written commun., 2004). 
The TAMA model simulates transient conditions from 1941 to 1999 by using 59 stress periods of 365 days each, and 12 time steps in each stress period. It simulates threedimensional ground-water flow in the regional aquifer system by using three layers. The layers delineate the major water-bearing units that are identified on the basis of regional hydrogeologic characteristics and stratigraphy. Model layer 1 is the saturated portion of the stream-channel alluvium and the Fort Lowell Formation and is simulated as an unconfined water-table aquifer. The Fort Lowell Formation is the most productive and heavily utilized water-bearing unit in the area. Model layer 2 consists of the upper Tinaja beds, which make up the next most productive unit in the modeled area. Layer 2 is simulated as a convertible aquifer that can switch from confined to unconfined conditions. Layer 3 contains all the water-bearing basin-fill deposits below the upper Tinaja beds. This layer includes the middle and lower Tinaja beds and the Pantano Formation. Layer 3 is simulated as a convertible aquifer that has a specified transmissivity. Layer 3 is the most aerially extensive model layer, but represents the least productive water-bearing unit. The tops and bottoms of the three model layers are defined on the basis of previous geologic investigations, well logs, and earlier ground-water model layer definitions (Anderson, 1987, 1988; Hanson and Benedict, 1994).

Boundaries for the TAMA model are along mountain fronts and at points of underflow into and out of the study area. The mountain fronts are represented as no-flow boundaries with specified fluxes representing mountain-front recharge assigned to active cells along the mountain fronts. During the transient simulation the inflow-outflow boundaries are simulated to allow the flux across a boundary to vary over time as the head at the boundary changes. Recharge from mountain-front, streamflow, and return infiltration, and inflow from adjacent basins are simulated by using the MODFLOW Recharge Package. Deep percolation of irrigation return flows, infiltration of effluent released into the channel of the Santa Cruz River, and seepage from mine tailings ponds also are, collectively, a large source of recharge within the regional model. Return flows are estimated to be a function of annual irrigation inefficiency and pumpage. The areal distribution of return-flow recharge was developed from agricultural pumpage and crop census reports.

Calibration of the TAMA transient model simulation was based on the following criteria: no model residual (difference between the simulated and observed water-level altitude) is greater than $150 \mathrm{ft}$; 95 percent of the absolute values of residuals are less than $75 \mathrm{ft}$; the mean absolute error for head residuals is less than $30 \mathrm{ft}$; the ratio of the root mean square error to the overall head loss in the system is equal to or less than 2 percent, and; hydrographs of measured waterlevel altitudes and simulated water-level altitudes during the simulation reasonably match. The mean absolute value for 950 residuals is $23 \mathrm{ft}$ with a standard deviation of $17.3 \mathrm{ft}$. The absolute value of the maximum residual is $95 \mathrm{ft}$, and the range is $+95 \mathrm{ft}$ to $-95 \mathrm{ft}$. The ratio of the root mean square error to the total head change in the model is 1.15 percent. Results from updated TAMA model simulations by the ADWR were provided to the author following the completion of this study. In the updated model, the ADWR has converted the regional model code to MODFLOW-2000 (Harbaugh and others, 2000). The use of MODFLOW-2000 enabled the observed heads to be weighted on the basis of their accuracy, which led to improved calibration statistics (Dale Mason, hydrologist, Arizona Department of Water Resources, written commun., 2004).

\section{Construction of Local Ground-Water Flow Model}

\section{Discretization}

Cells in the local model are $528 \mathrm{ft}$ on a side and are orientated on the same north-south and east-west grid as cells in the TAMA model; therefore, there are 25 local cells within each TAMA cell. Local-model layering is the same as that in the TAMA model.

\section{Boundary Conditions}

MODTMR specifies the boundary condition type for all local-model perimeter cells, including those in inactive areas of the regional model. Specified-flow boundaries are assigned on all perimeter cells with the exception of the northwest-most cell of the local model, which is a specifiedhead cell. The specified flow along the local-model perimeter is defined by the flow crossing the local-model boundary from the TAMA model and is defined for each perimeter cell for each layer and for each time step and stress period. The specified head in the northwest-most model cell represents the head in the aquifer at that location within the TAMA model and is specified for each layer and each time step and stress period. A specified flow of 0 is assigned to inactive areas.

The amount of recharge within the local model is the same as that used in the corresponding area of the TAMA model. Mountain-front recharge occurs in ephemeral washes and through alluvial fans along the fronts of the Santa Catalina Mountains upgradient from Rillito Creek. The amount and distribution of mountain-front recharge applied in the local model were maintained from the TAMA model by using the Recharge Package. Estimates of annual mountain-front 
recharge for the TAMA model were developed from values used in the Hanson and Benedict (1994) ground-water flow model. Recharge from streamflow infiltration occurs in stream channels of the Santa Cruz River, Rillito Creek, Pantano Wash, and Tanque Verde Creek. The amount and distribution of stream-channel recharge applied in the local model were maintained from the TAMA model by using the Recharge Package and the Stream Package. The Stream Package was used along Rillito Creek, whereas the Recharge Package was used elsewhere.

The amount of pumpage within the local model is the same as that used in the corresponding area of the TAMA model. In this area, ground-water pumping increases between 1940 and the late 1990s. In the late 1990s several wells were retired as a portion of ground-water pumpage was shifted to Avra Valley - the adjacent basin to the west. Pumpage values beyond 2000 were projected to 2025 by the ADWR (Dale Mason, hydrologist, Arizona Department of Water Resources, written commun., 2003). The projected values indicate a gradual increase in pumpage from the early 2000s to 2025 .

\section{Simulation of Recharge}

The TAMA model used to create boundary conditions for the local model simulates recharge with the Stream Package for cells coincident with Rillito Creek. When the Recharge Package is used, the total recharge is the sum of specified recharge for individual cells traversed by Rillito Creek. When the Stream Package is used, the total recharge is controlled by the amount of surface flow specified at the upper end of Rillito Creek for most scenarios discussed in this report. Although the amount of recharge applied by using the Stream Package is the same as that applied by using the Recharge Package in the TAMA model, the distribution of recharge is slightly different (fig. 3). The greatest differences between the two model simulations are in the upper reaches where the Stream Package simulations result in less recharge than the Recharge Package simulations, and in the middle reaches where Stream Package simulations result in more recharge than Recharge Package simulations. These differences are related to the distribution of streambed-conductance terms used in the Stream Package. The variation in streambed-conductance terms can be justified on the basis of the findings of Hoffmann and others (2002) as explained in the following discussion on the use of the computer program RIVGRID.

The recharge distribution resulting from the use of the Stream Package agrees better with results from seepage measurements and microgravity surveys than with the distribution simulated by using the Recharge Package (Pool and Schmidt, 1997; Don Pool, hydrologist, U.S. Geological Survey, written commun., 2003). About 66 to 89 percent of streamflow losses during sustained flows in Rillito Creek occur in the middle reach. The low recharge rates in the upper reaches are related to the shallow depths to ground water. The greater depths to water in the middle reaches allow for more storage for the infiltrating water.

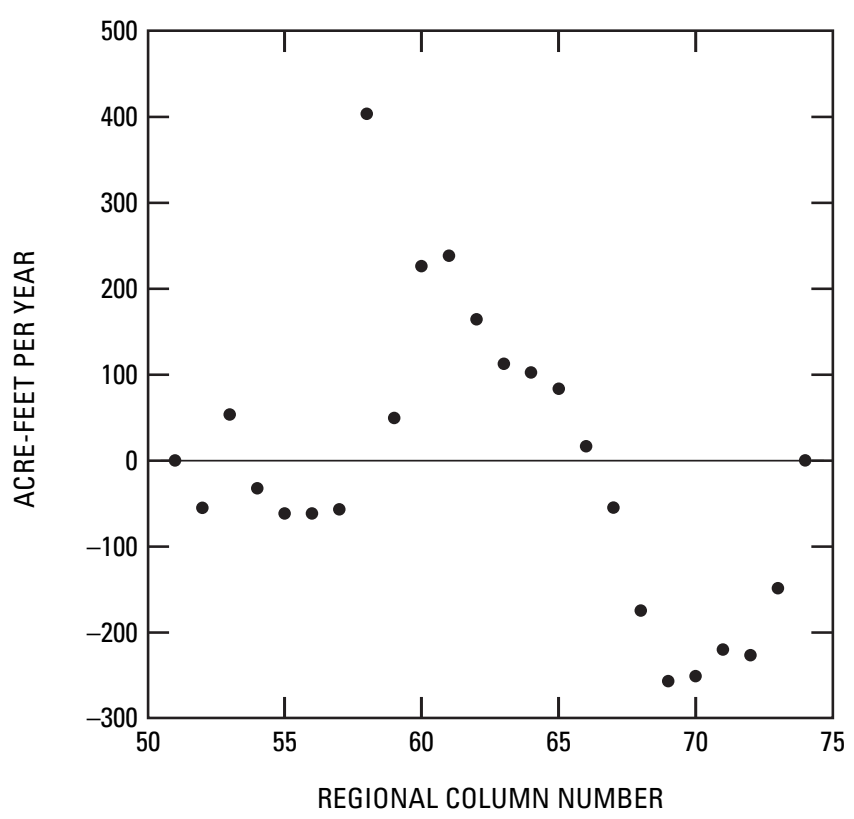

Figure 3. Difference in the distribution of recharge applied to the steady-state local model between the Recharge and Stream Packages, Rillito Creek, Arizona. Positive values indicate more recharge is simulated by the Stream Package.

Simulated water-level altitudes that result from recharge distributions created by the Recharge and Stream Packages are similar for both steady-state and transient simulations (fig. 4); however, small systematic differences are evident within the local-model area. For instance, in the steady-state simulations, the water-level altitude differences are greatest on the eastern side of the local model, and for the transient simulations differences are greatest on the western side of the local model. The differences are typically about $5 \mathrm{ft}$ for the steady-state simulation and can be as much as $30 \mathrm{ft}$ at the end of the transient period in 1999. These differences in simulated water-level altitudes between recharge application methods are considered small given the range in water-level variations over the model area.

Recharge to cells that represent Rillito Creek was simulated as varying over time. Between 1941 and 1999, total recharge for model cells coinciding with Rillito Creek ranged from about 4,900 to 6,000 acre-ft/yr (fig. 5). Recharge values applied to the calibrated model were simplified to a step function for use in the Stream Package (fig. 5). Recharge in the regional model that is used to create input data sets and boundary conditions for the local model was applied at a rate of about 4,900 acre-ft/yr for 1941-1954, at a rate of about $5,500 \mathrm{acre}-\mathrm{ft} / \mathrm{yr}$ for $1955-1963$, at a rate of about 6,000 acre$\mathrm{ft} / \mathrm{yr}$ for 1964-1980, and at a rate of about 4,900 acre-ft/yr for 1981-1999. 
A. Steady state, 1940

\section{EXPLANATION}

WATER-LEVEL ALTITUDE FOR STEADY-STATE SIMULATIONS IN FEET ABOVE NGVD OF 1929 CONTOUR INTERVAL 20 FEET:

\section{$-2,220-$ RECHARGE PACKAGE SIMULATION \\ $--2,320-\quad$ STREAM PACKAGE SIMULATION}

B. Transient, 1999

\section{EXPLANATION}

WATER-LEVEL ALTITUDE FOR

TRANSIENT SIMULATIONS,

IN FEET ABOVE NGVD OF 1929

CONTOUR INTERVAL 20 FEET:

$-2,220-$ RECHARGE PACKAGE SIMULATION

$-\mathbf{2 , 1 8 0}-\quad$ STREAM PACKAGE SIMULATION

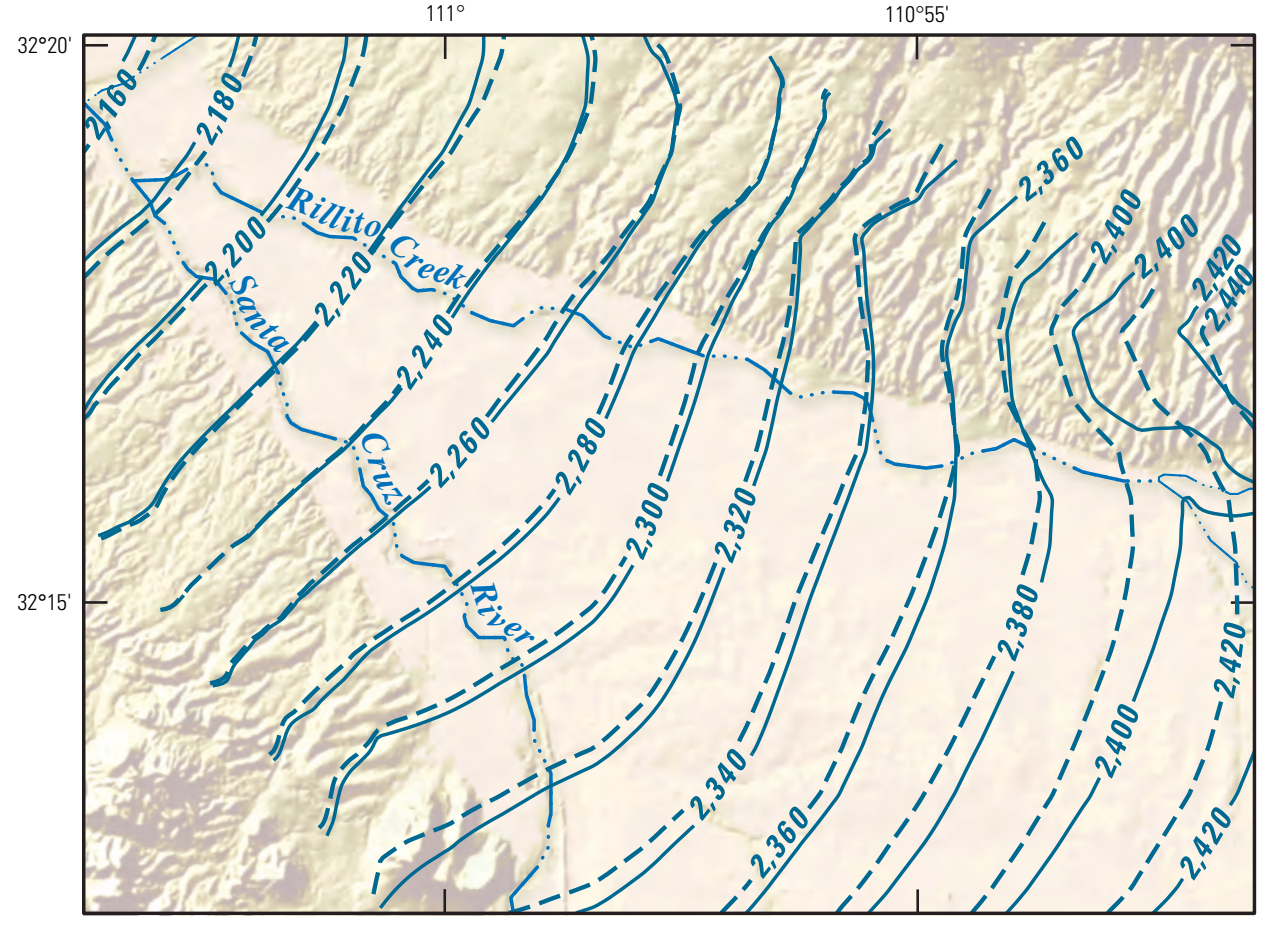

Base from U.S. Geological Survey

digital data, $1: 100,000,1982$

projection, Zone 12
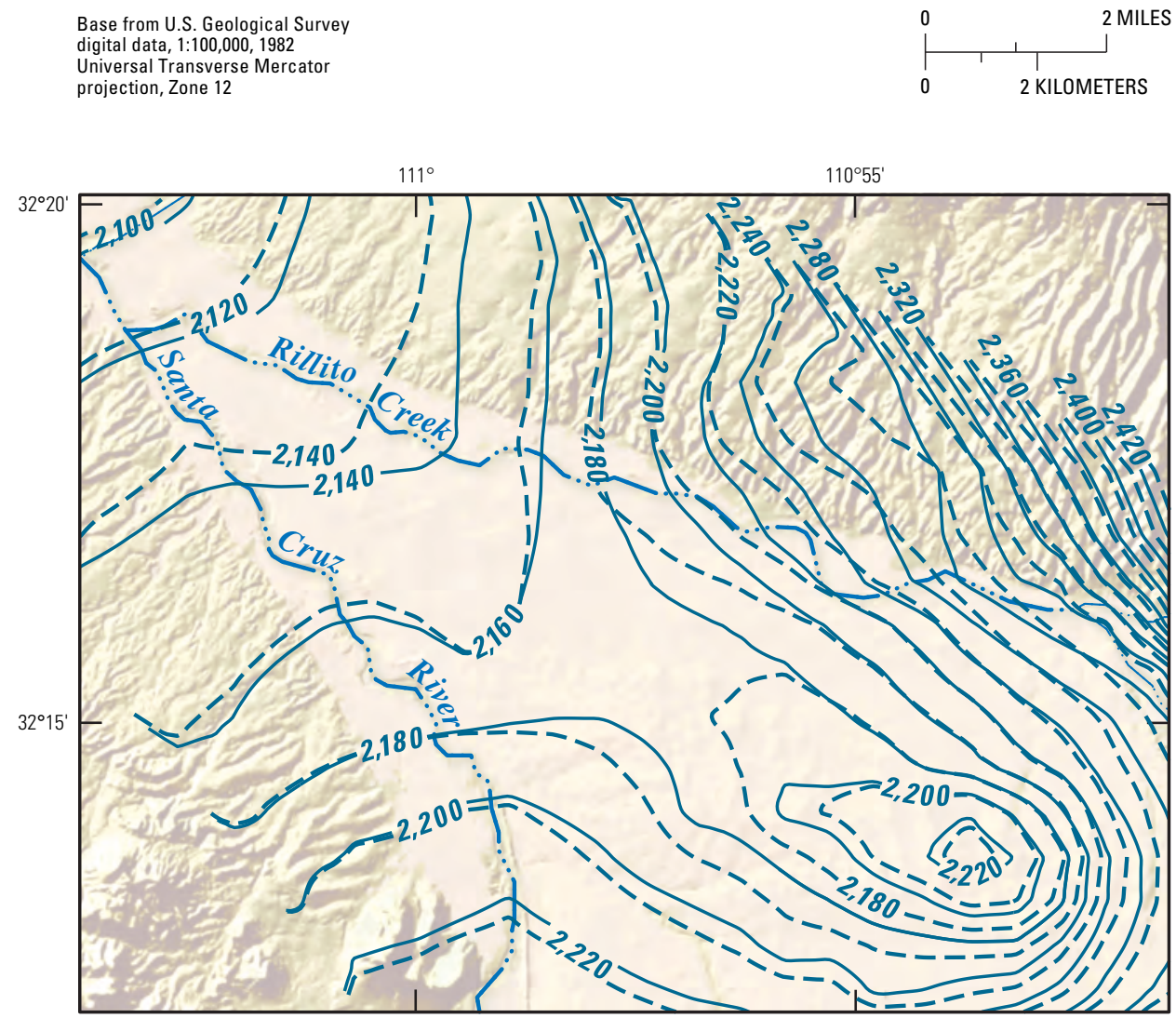

Figure 4. Simulated water-level altitude in layer 2 of the local model using the Recharge and Stream Packages along Rillito Creek, Tucson, Arizona. A, Water-level altitude for steady-state simulations, 1940; B, Water-level altitude for transient simulations, 1999. 


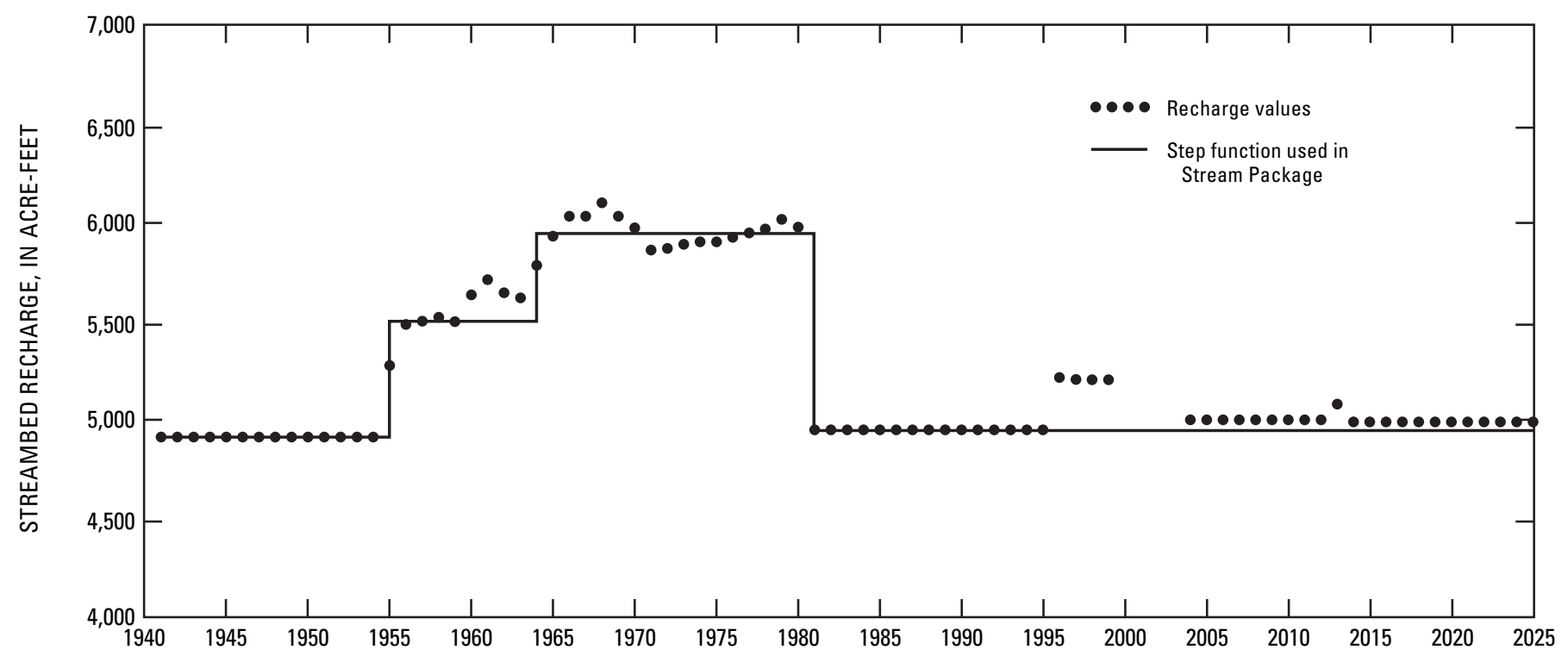

Figure 5. Recharge to model cells coinciding with Rillito Creek, Tucson, Arizona, 1941-2025.

The computer program RIVGRID was used to calculate streambed conductances used in the Stream Package. The streambed conductance $\left(\mathrm{L}^{2} / \mathrm{T}\right)$ is the hydraulic conductivity of the streambed multiplied by the product of the width of the streambed and its length divided by the thickness of the streambed. Hydraulic conductivity values and streambed widths and thicknesses were varied spatially in RIVGRID on the basis of findings of Hoffmann and others (2002). Particle-size analyses of cores and cuttings and DC electricalresistivity surveys indicated that, in general, streambed deposits in the upper two-thirds of Rillito Creek are coarser grained than the deposits in the lower third. In addition, a fine-grained deposit below the streambed but above the water table exists in the lower third of Rillito Creek. Although streambed material in the uppermost reach is coarser grained than that in the middle reach, it also is poorly sorted and has a larger fraction of fine-grained material. Owing to variations in grain-size distribution, the middle reaches have the largest streambed-conductance values and the lower reaches have the smallest values.

MODFLOW's Stream Package computes leakage to or from the stream by using Darcy's Law as the product of the conductance term and the difference between the head in the stream and the head in the aquifer. Head in the stream is calculated in the Stream Package by using the Manning formula (Ozbilgin and Dickerman, 1984). Manning's roughness coefficients used in this equation were based on literature citations (White, 1979).

\section{Comparisons of Water Levels from Local and Regional Models}

\section{Steady State}

Steady-state water-level altitudes simulated by using the Stream Package in the local and TAMA models are in good agreement (fig. 6). Water levels within the local-model area in both the TAMA and local steady-state simulations range from about 2,420 ft in the southeast to about 2,160 ft in the northwest. The difference in water-level altitudes between the local model and the TAMA model for layer 2 averages about $3 \mathrm{ft}$ and is generally less than $13 \mathrm{ft}$. The largest differences between the local and TAMA models occur in the northeastern part of the local model near inactive cells and at the southern boundary of the local model (fig. 6). The difference in water levels in the northeastern part of the model area probably is related to boundary effects near the inactive part of the model in this area. This agreement provides confidence that the local model is a fair representation of the TAMA model and thus can be used to test transient simulations. 
A. Steady state, 1940

EXPLANATION

WATER-LEVEL ALTITUDE FOR STEADY-STATE SIMULATIONS, IN FEET ABOVE NGVD OF 1929 CONTOUR INTERVAL 20 FEET:

- 2,240 — REGIONAL MODEL

$\cdot 2,320$.. LOCAL MODEL

B. Transient, 1999

\section{EXPLANATION}

WATER-LEVEL ALTITUDE FOR TRANSIENT SIMULATIONS, IN FEET ABOVE NGVD OF 1929 CONTOUR INTERVAL 20 FEET:

- 2,180 — REGIONAL MODEL

$\bullet 2,240$ •. LOCAL MODEL

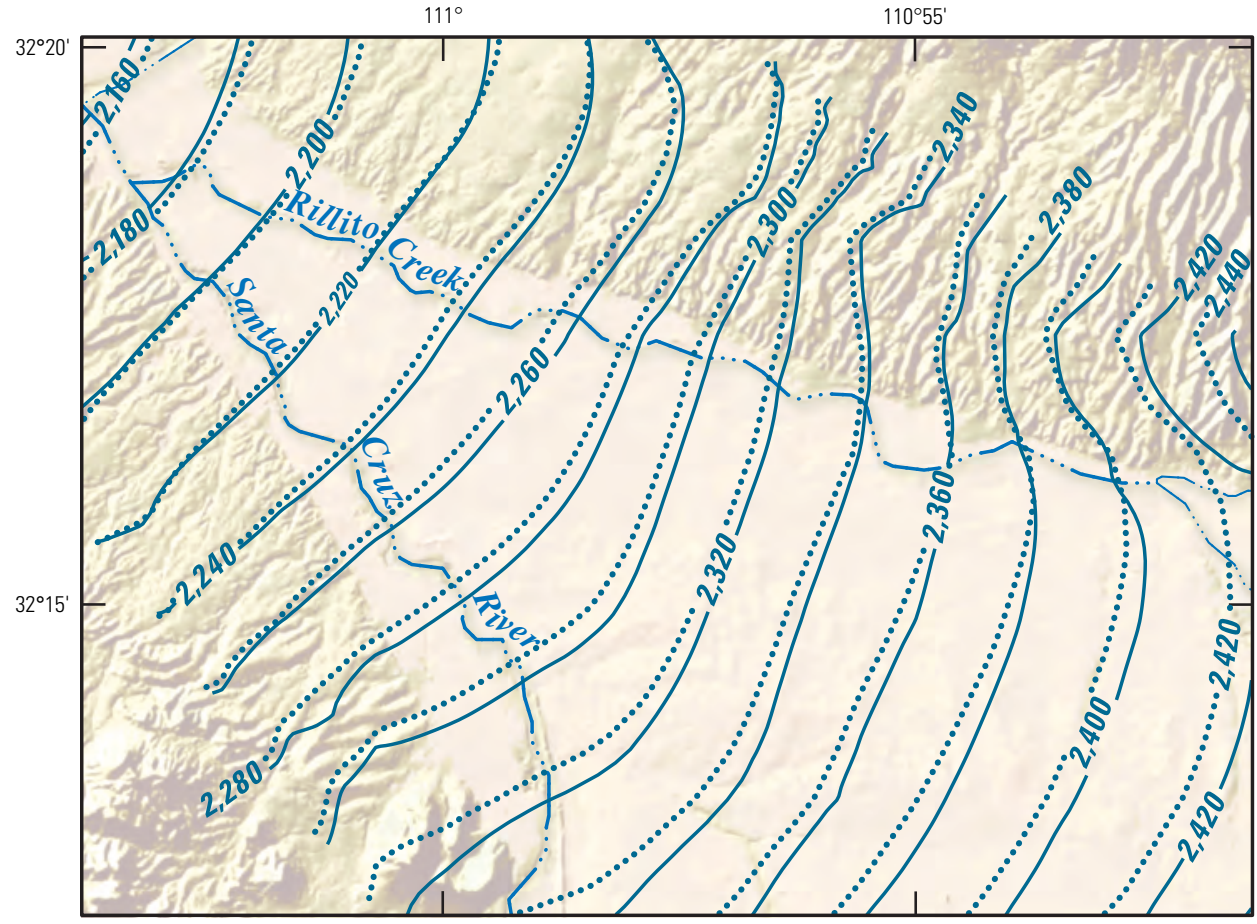

Base from U.S. Geological Survey digital data, 1:100,000, 1982

projection, Zone 12
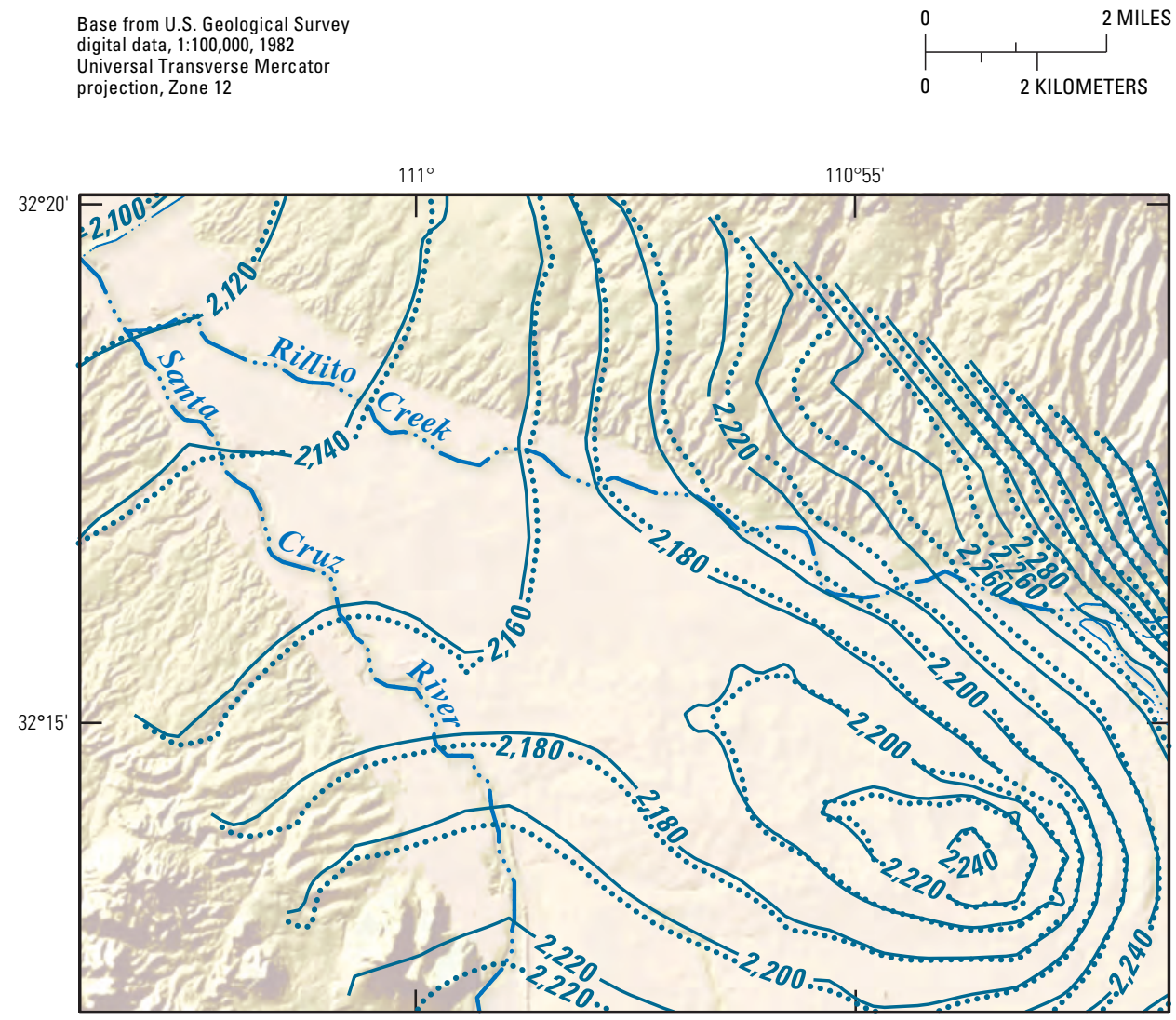

Figure 6. Simulated water-level altitudes in layer 2 for regional and local models using the Stream Package along Rillito Creek, Tucson, Arizona. A, Steady-state simulation, 1940; B, Transient simulation, 1999. 


\section{Transient}

Simulated transient water-level altitudes in the TAMA and local models are in good agreement (fig. 7). Transient water-level altitudes in the TAMA and local models were compared to each other in plan view and at specific observation cells. Dewatering of the aquifer represented by layer 1 caused the aquifer represented by layer 2 to become the predominant aquifer in the area; therefore, water-level altitudes for model layer 2 are shown for all comparisons. In addition, water-level altitudes in layer 2 can be used as an estimate for altitudes in layers 1 and 3; where the layers are saturated, water-level altitudes in the layers are similar (fig. 7). In general, the temporal water-level trend shown in figure 7 is representative of the modeled area and shows a decline in the water-level altitude near Rillito Creek and within the Central Well Field from 1941 to 1999. The difference in water-level altitude between the three model layers is less than $6 \mathrm{ft}$ and generally less than $1 \mathrm{ft}$.

The simulated water-level altitudes plotted in plan view allows for assessment of spatial variations in water levels, whereas simulated water-level altitudes through time at selected observation cells allows for assessment of temporal variation. Water-level altitudes in 1999 for both the TAMA and local transient simulations range from about 2,420 ft in the eastern part of the local model to about 2,100 ft in the northwestern part (fig. 6B). The difference in water-level altitudes between the local and TAMA models averages about $3 \mathrm{ft}$. The maximum differences between the local and TAMA models (about $30 \mathrm{ft}$ ) occur in the northeastern part of the local model near an inactive part of the model. The difference in water-level altitudes in the northeastern part of the model area probably is related to nearby inactive model cells and local-model discretization. The difference in simulated water-level altitudes between the two models is considered small and is relatively constant with time (fig。 8). The small differences in water-level altitudes between the two models provide confidence that the transient local model is a fair representation of the transient TAMA model and thus can be used to test forecast simulations based on a variety of recharge scenarios.

\section{Simulated Water Levels, Ground- Water Fluxes, Storage Changes, and Evapotranspiration}

Simulated water-level, ground-water flux, storage, and ET responses to four recharge scenarios are discussed in this section. The amount of recharge applied for each scenario, resulting from streambed leakage through Rillito Creek, is shown in figure 9. Recharge scenarios arbitrarily begin in 2005 and are extended to 2225 to evaluate long-term effects. Recharge in scenario A (5,000 acre-ft/yr) represents longterm natural recharge conditions (no change in recharge rates relative to 1999). For this scenario, an upstream streamflow discharge of 5,000 acre- $\mathrm{ft} / \mathrm{yr}$ is routed along Rillito Creek by using the Stream Package.

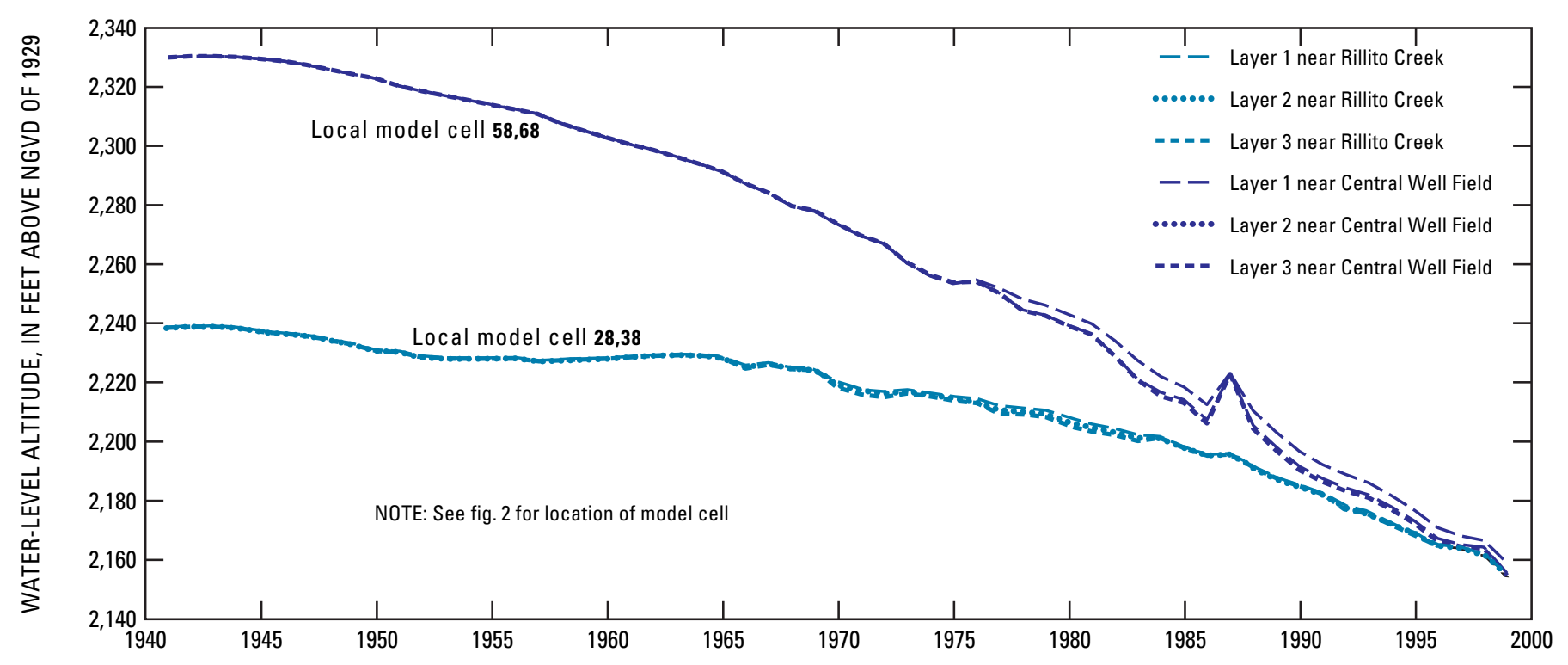

Figure 7. Hydrographs for selected local-model cells near Rillito Creek and the Central Well Field for model layers 1, 2, and 3, Tucson, Arizona, 1941-99. 


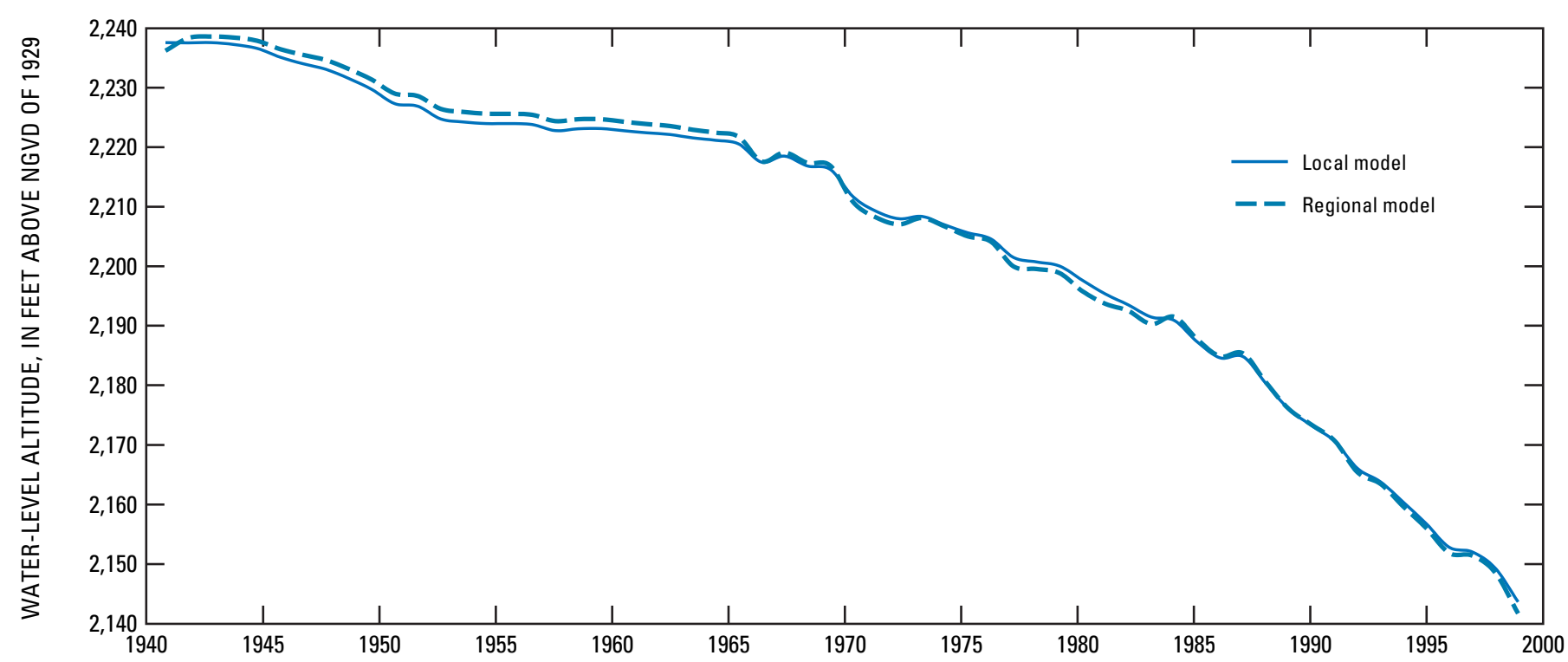

Figure 8. Hydrograph for selected cell 28,38, layer 2, in the local and regional models, 1941-99, Rillito Creek, Arizona.

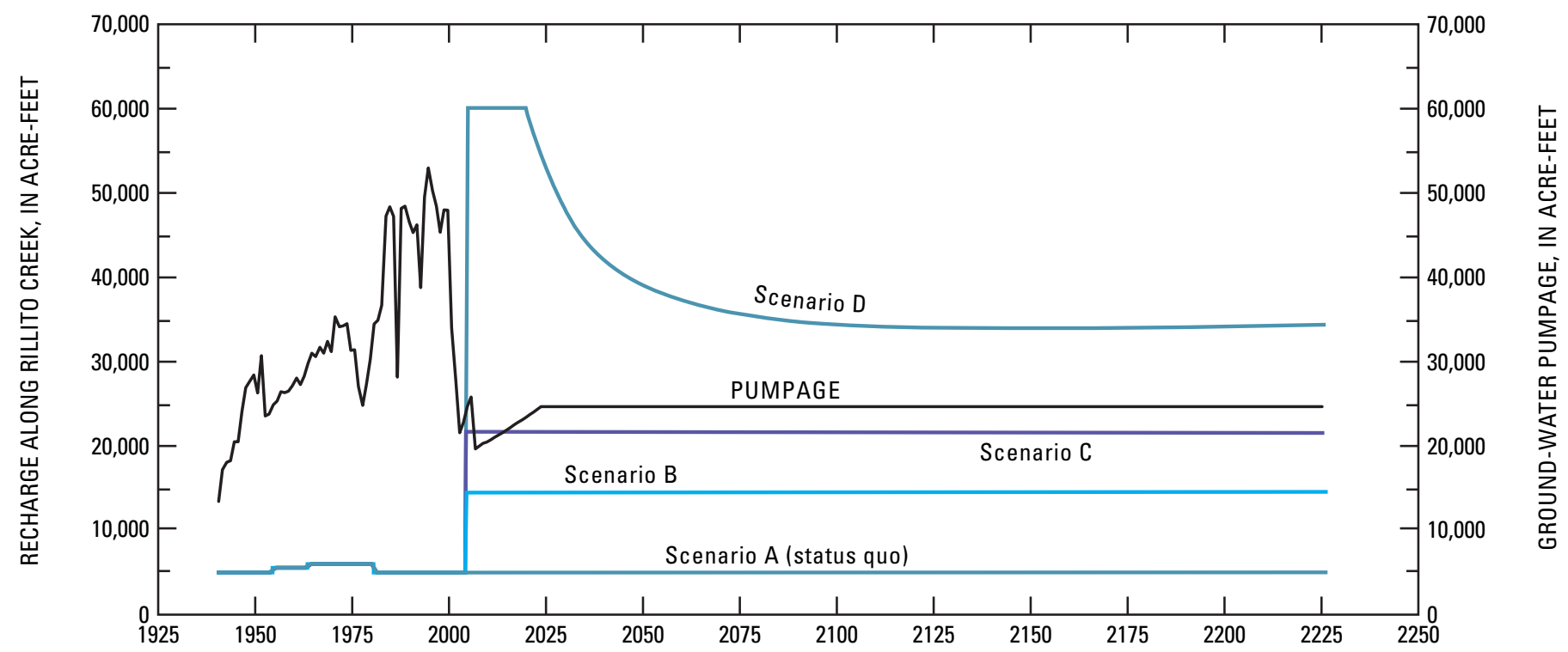

Figure 9. Amount of streambed recharge applied to the local model using the Stream Package along Rillito Creek, Arizona, and pumpage for each scenario.

Scenario B almost triples the amount of annual recharge by using a constant recharge rate of 14,500 acre-ft/yr. Scenario C uses a constant recharge rate of about $21,000 \mathrm{acre}-\mathrm{ft} / \mathrm{yr}$. For each of these scenarios, an upstream discharge equal to the total amount of recharge along Rillito Creek is routed through the creek by using the Stream Package. Discharge at the upstream-most cell starts as 5,000, 14,500, and 21,000 acre-ft for scenarios A, B, and C, respectively, and owing to infiltration along the course of the creek, flow gradually tapers to zero near the confluence with the Santa Cruz River. Scenar- io D starts with a recharge rate of 60,000 acre-ft/yr for the first 15 years and gradually tapers to about 34,000 acre-ft/yr. The 60,000 acre-ft/yr rate represents the maximum amount of CAP water available for artificial recharge along Rillito Creek. Simulations attempting a recharge rate of 60,000 acre- $\mathrm{ft} / \mathrm{yr}$ could not be maintained and resulted in water being routed past the confluence with the Santa Cruz River. A discussion on simulated water-level, ground-water flux, storage, and ET responses that occur prior to the onset of recharge scenarios is provided first as an evaluation of historical trends. 


\section{Prior to Simulated Recharge Scenarios, 1941-2004}

Before recharge values are adjusted for 2005 for the respective scenarios, each simulation is run from 1941 through 2004; recharge values used from 1941 through 1999 are based on values from the TAMA model. Recharge values from 2000 to 2004 are held constant at 5,000 acre-ft/yr, which represents the value used along Rillito Creek in the forecasted transient simulation of the TAMA model.

\section{Water Levels}

Simulated hydrographs for selected cells (fig. 10) show a steady water-level decline for the period between 1941 and 2003 associated with increased pumpage within the Central Well Field (fig. 9). These hydrographs show a small rise in water level for most of the area starting in about 2003. The water-level rise is related to the recent and proposed retirement of several Central Well Field production wells (Dale Mason, hydrologist, Arizona Department of Water Resources, written commun., 2003) that began in 1995.

\section{Ground-Water Flux}

Ground-water fluxes southward past line segment 1 (fig. 11) and northwestward past line segment 2 (fig. 12) are shown for the transient period prior to the recharge scenarios and for all recharge scenarios that extend to the year 2225. Ground-water flux past these line segments varies with time and is related to water-level gradients and aquifer transmissivity. Flux is calculated by using a linear interpolation method described by Leake and Claar (1999).

Line Segment 1.- Near the start of the transient simulation, all water flowing past line segment 1 is flowing northward at a rate of about 5,200 acre-ft/yr. The flux past line segment 1 is northward from 1941 to 1963 because of the general northwestward hydraulic gradient of the regional aquifer. During this time period, flux northward decreases about 260 acre-ft/yr as pumpage from the Central Well Field reduces the hydraulic gradient to the north. After 1963 the net total flux is southward toward the Central Well Field and continues to increase at a steady rate until it reaches a maximum of 7,670 acre-ft/yr in 1996. As pumpage from the Central Well Field declines (fig. 9), the southward flux of ground water also declines, and by 2004, southward flux is about 4,300 acre-ft/yr.

Line Segment 2. - Near the start of the transient simulation, all water flowing past line segment 2 flows northwestward at a rate of about 6,400 acre-ft/yr. The net total flux is northwestward during the entire transient simulated period because of the hydraulic gradient of the regional aquifer; however, there is a decline in flux from 6,000 acre-ft/yr in 1970 to about 1,320 acre-ft/yr in 2004 (fig. 12). The relative contribution of ground-water flux varies with time; however, layer 1 provides most of the flux across line segment 2 from 1941 to 1996, and layer 2 provides most of the flux after 1996.

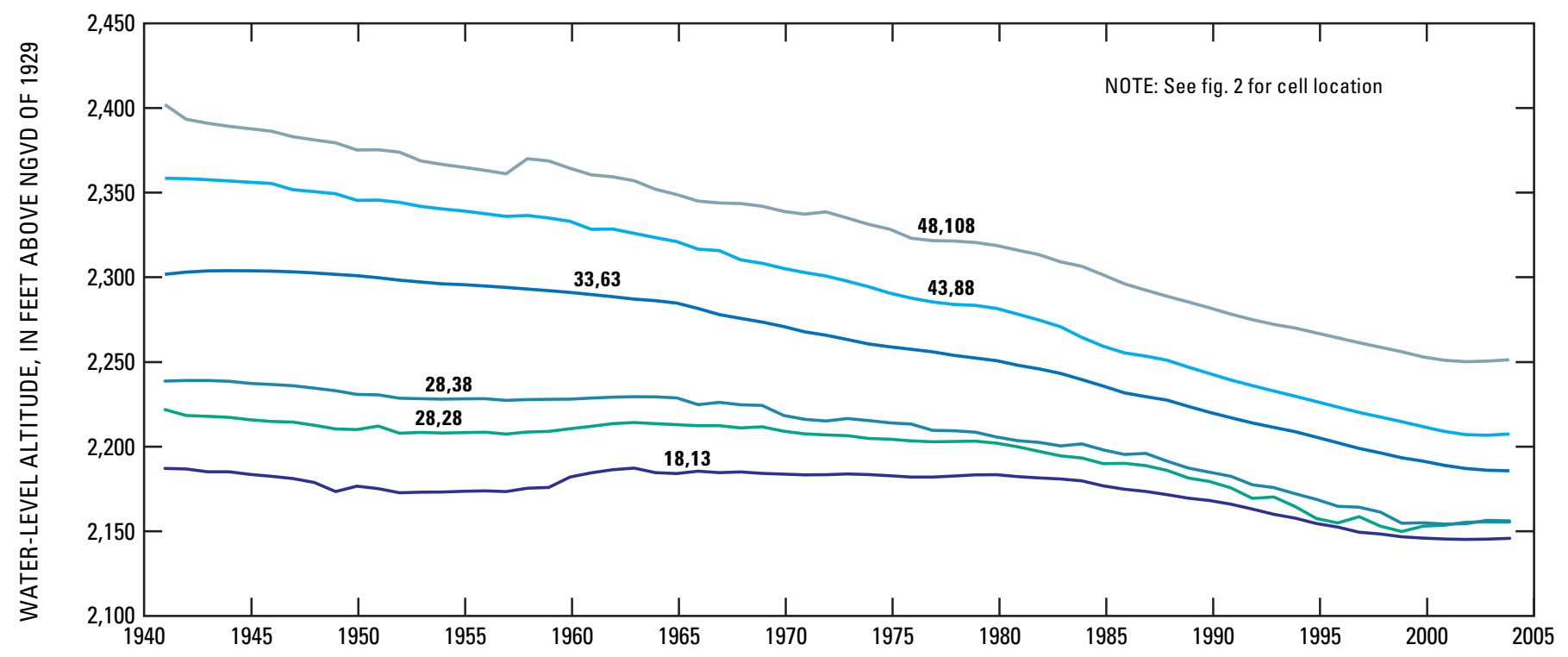

Figure 10. Simulated hydrographs for selected cells in the local model, Rillito Creek, Arizona, 1941-2004. 


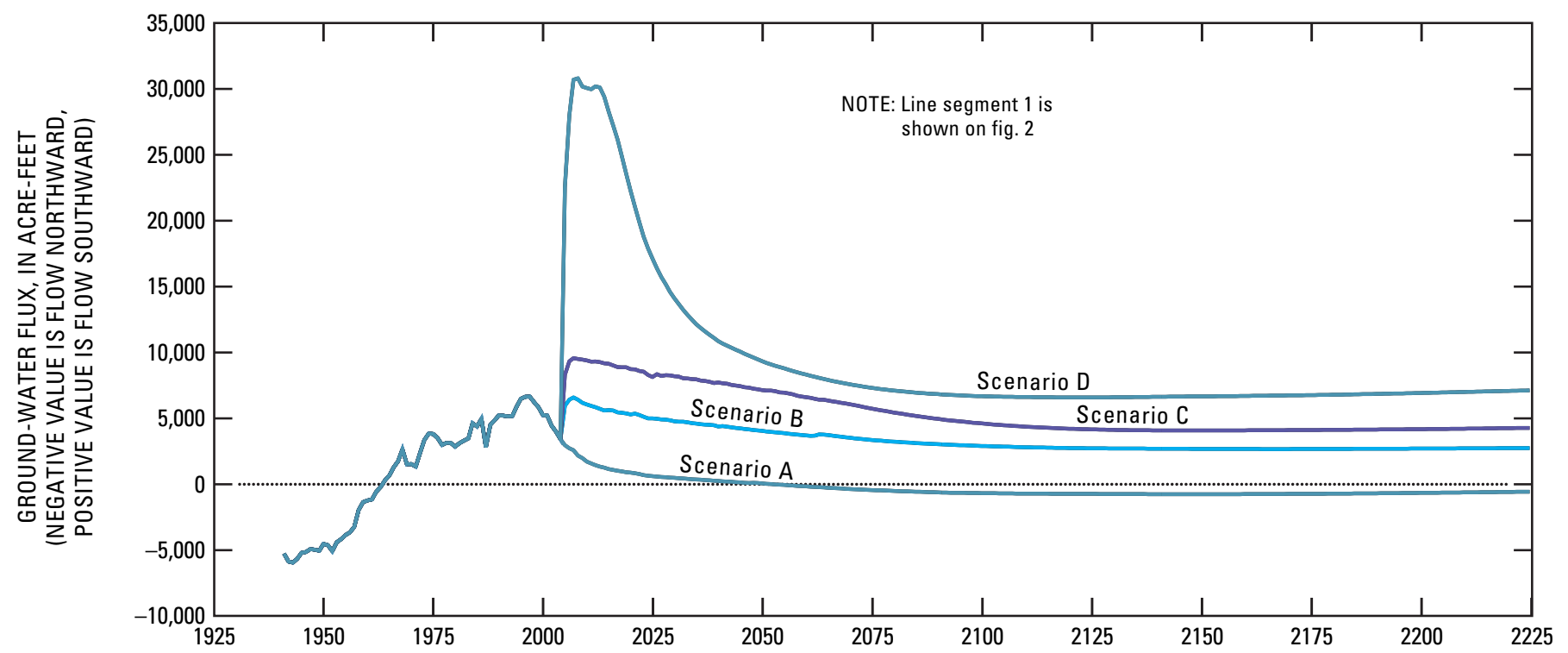

Figure 11. Simulated annual ground-water flux past line segment 1 in the local model, Rillito Creek, Arizona, 1941-2225.

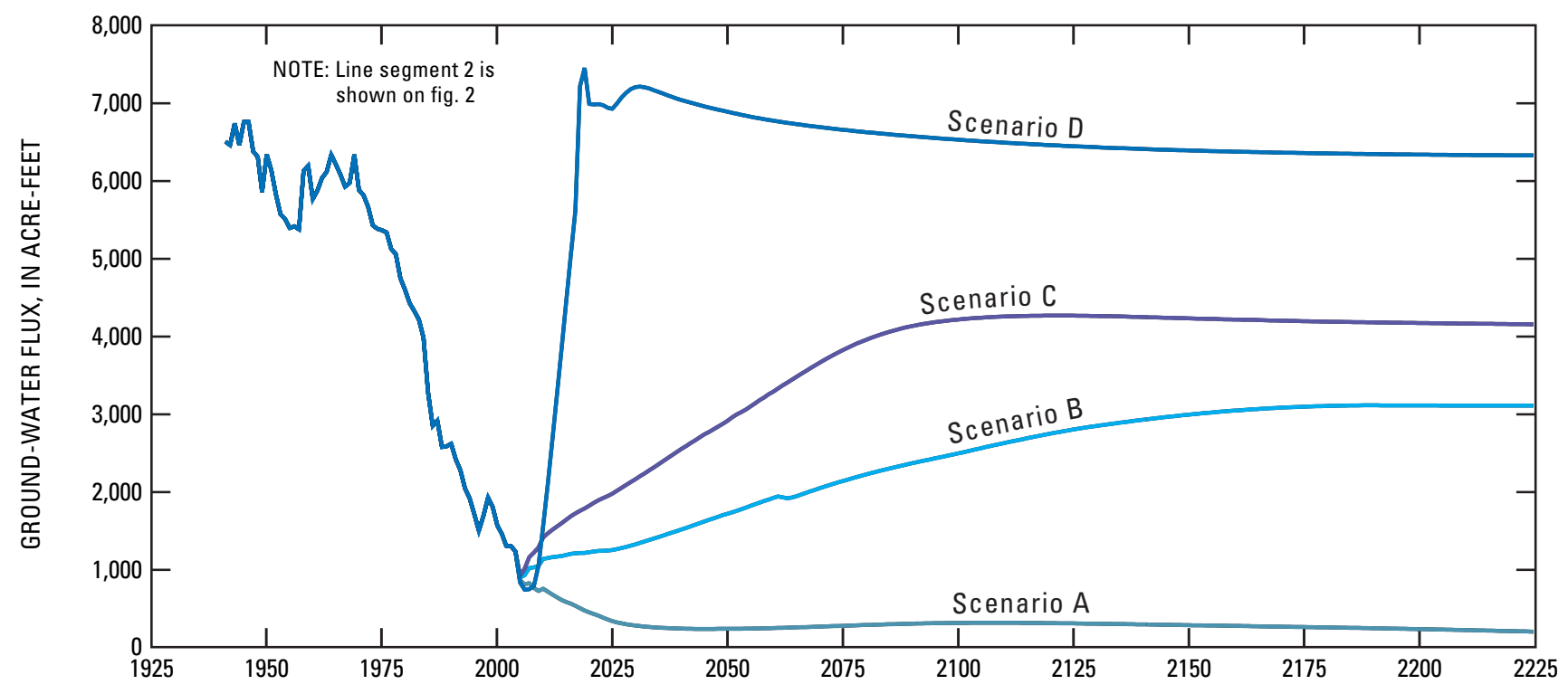

Figure 12. Simulated annual ground-water flux past line segment 2 in the local model, Rillito Creek, Arizona, 1941-2225. 


\section{Storage}

The loss of ground water from storage in the local-model area steadily increased until 1995 owing to the increasing pumpage rates within the modeled area during this period (fig. 13). As pumpage is reduced, water levels rise, resulting in positive storage changes.

\section{Evapotranspiration}

Ground-water discharge as ET from the local-model area is about 3,800 acre-ft/yr in 1941 and steadily declines to less than 500 acre-ft/yr by 1957 owing to a falling water table (fig. 14). Discharge of shallow ground water as ET continues to decline gradually from 1957 to 1985 ; from 1985 to 2004 discharge is nearly constant at about 200 acre-ft/yr.

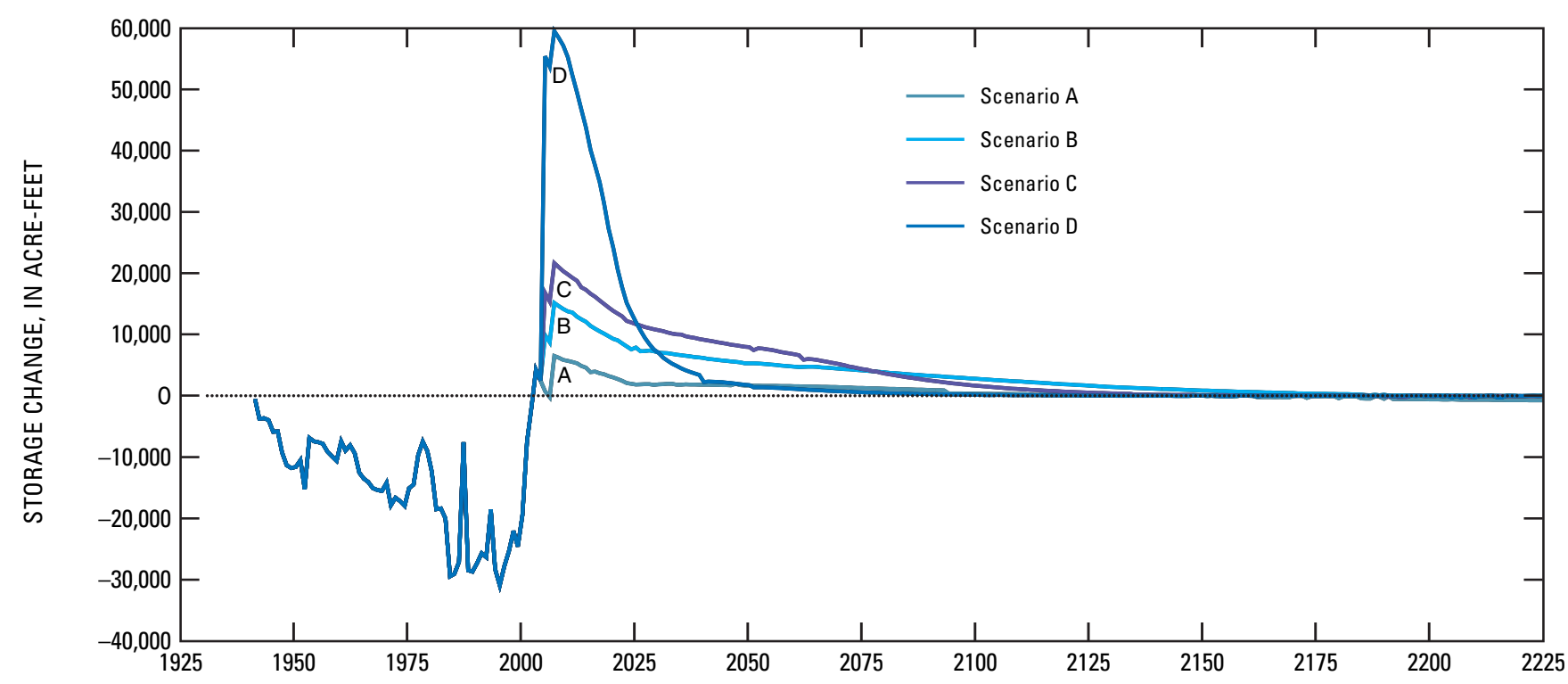

Figure 13. Simulated annual change in ground-water storage in the local model, Rillito Creek, Arizona, $1941-2225$.

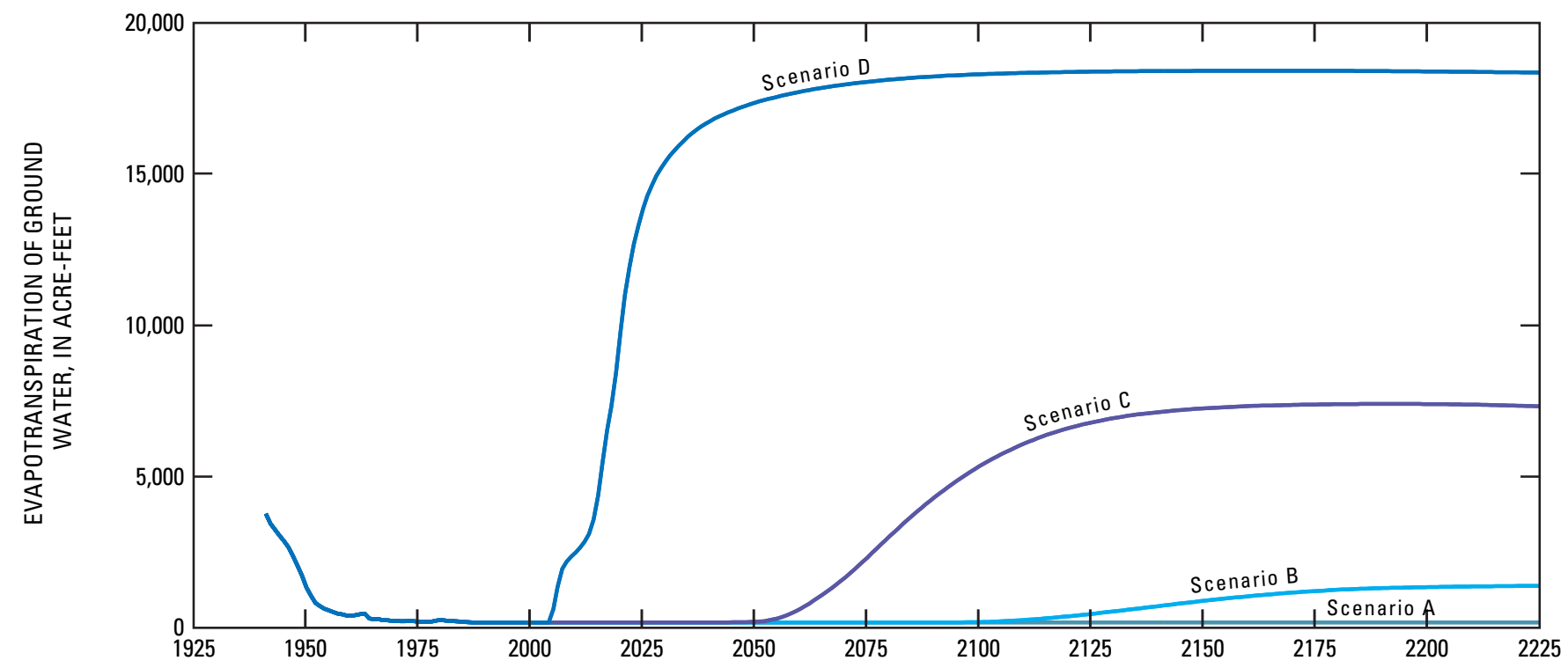

Figure 14. Simulated annual loss of ground water due to evapotranspiration in the local model, Rillito Creek, Arizona, $1941-2225$. 


\section{Scenario A-Continued Recharge at Forecasted Natural Recharge Rates, 2005-2225}

Water-level altitudes, ground-water fluxes, storage changes, and ET are discussed for scenario A in absolute terms. Scenario A is considered the base-case scenario to which all other scenarios are compared.

\section{Water Levels}

Simulated hydrographs for specific cells within the local model that represent sites near recharge areas and within the Central Well Field (fig. 15) show a general increase in water-level altitude for most of the area. Cells distant from the Central Well Field, however (for example, cells 18,13; and 28,38; in fig. 15), show a small but continuous decline in water-level altitude. The overall increase in water-level altitude is a continuation of the increase that began around 2003 and is related to the recent and proposed retirement of several Central Well Field production wells (Dale Mason, hydrologist, Arizona Department of Water Resources, written commun., 2003) that began in 1995. Water-level altitude maps are shown for the end of 2004, 2015, 2025, 2050, 2100, and 2225 (fig. 16). These times were chosen to show altitudes at specific times of interest and to show areal changes that are related to the transient response of the hydrographs shown in figure 15 . For instance, the initial water-level altitude map for the end of 2004 represents the water level of the ground-water system immediately prior to the recharge scenarios; 2025 represents the final year of ADRW's projected pumpage estimates and the year that the TAMA is mandated to reach "Safe Yield" (Arizona Department of Water Resources, 2004); and 2225 represents the end of all scenario simulations. Other times are shown to represent changing water-level altitudes over time.

\section{Ground-Water Flux}

Line Segment 1.-The southward hydraulic gradient across line segment 1 is reduced owing to the general decline in pumpage from the Central Well Field and associated water-level changes; thus, southward flux of ground water declines from 3,400 acre-ft/yr at the end of 2004 to about 2,000 acre-ft/yr by 2015 (fig. 11). By 2053 the flux across line segment 1 becomes negative, indicating the flux is northward. After about 2100, the net flux northward is fairly constant, ranging from about 500 to 750 acre-ft/yr (fig. 11). The amount of ground-water flux past line segment 1 for each layer varies with time; however, layer 2 provides most of the flux across line segment 1 except during 2024-2057 when the amount of flux in layer 1 is greater. Although the net flux for all layers becomes northward after 2053, the direction of ground-water flux in layer 1 is southward for the duration of the simulation and ranges from about 200 to $500 \mathrm{acre}-\mathrm{ft} / \mathrm{yr}$.

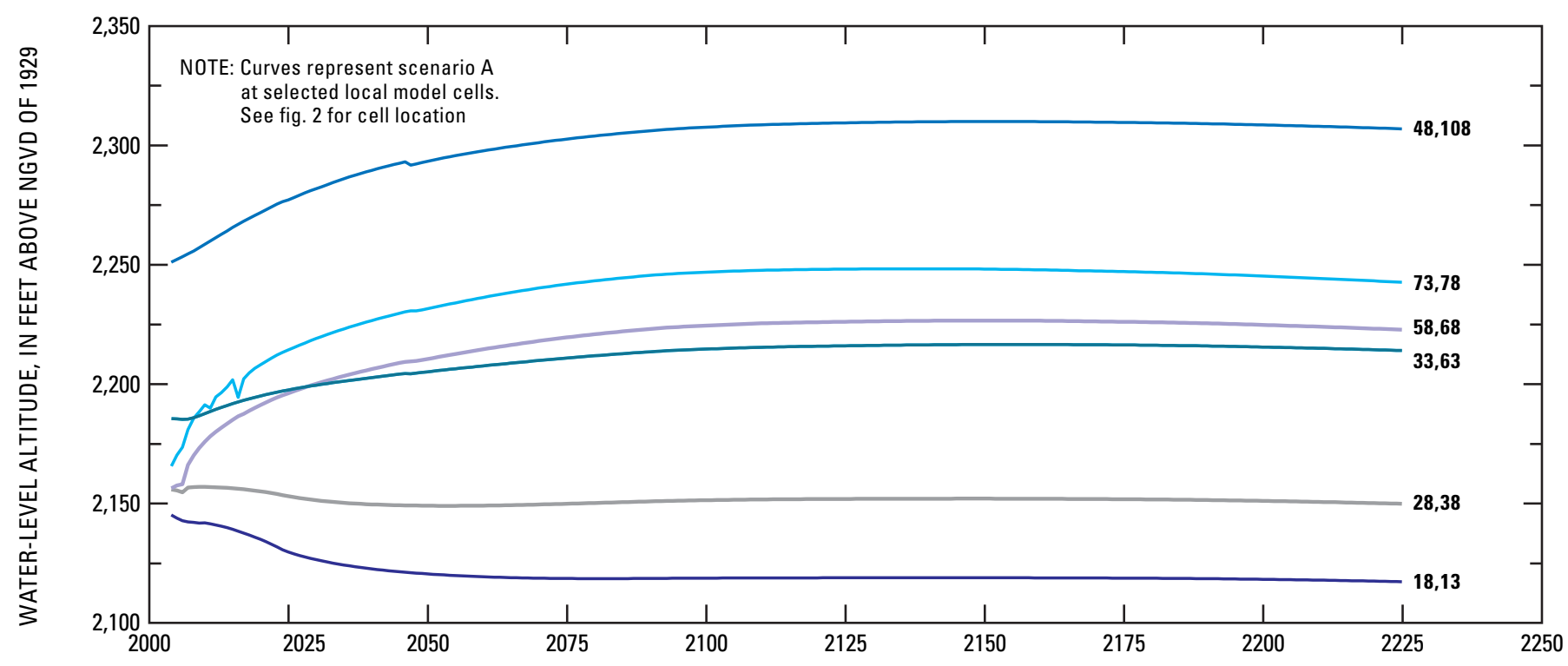

Figure 15. Hydrographs for selected cells in the local model, Rillito Creek, Arizona, 2005-2225. 
A. 2004

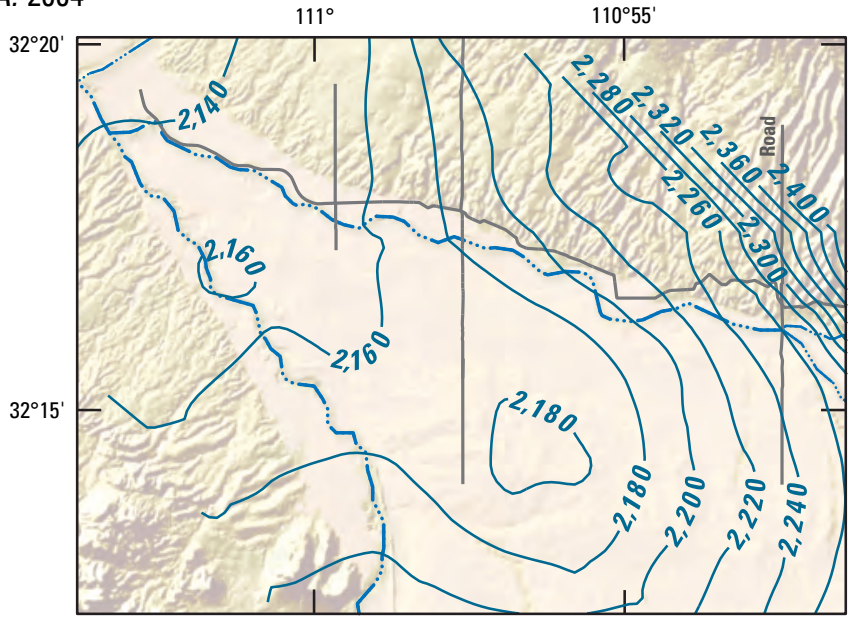

C. 2025

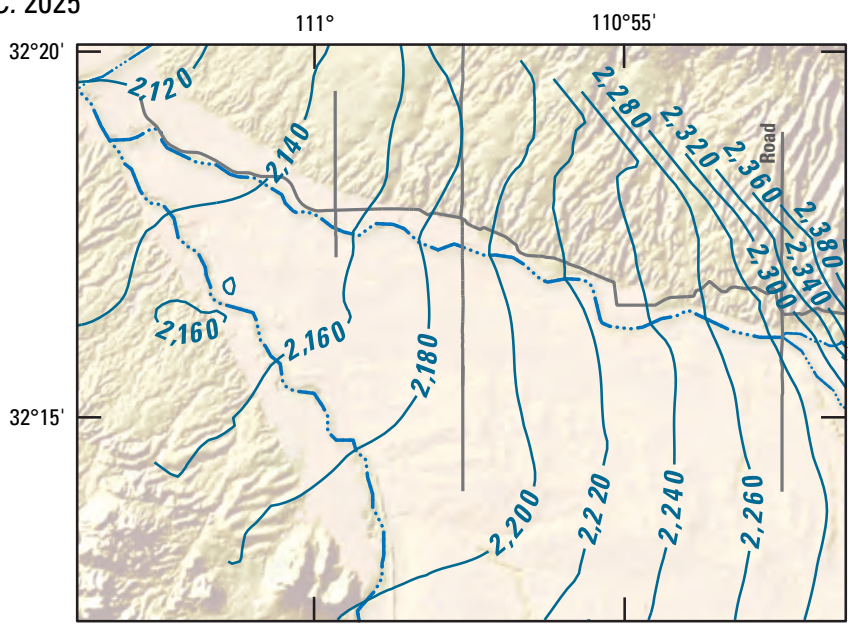

E. 2100

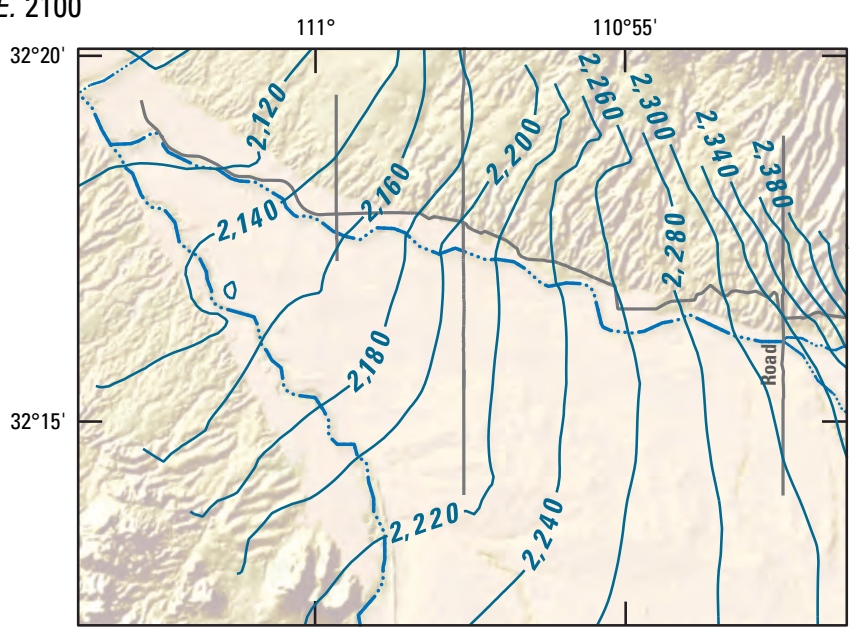

EXPLANATION

- 2,300 - WATER-LEVEL ALTITUDE FOR SCENARIO A, IN FEET ABOVE NGVD OF 1929. CONTOUR INTERVAL 20 FEET
B. 2015

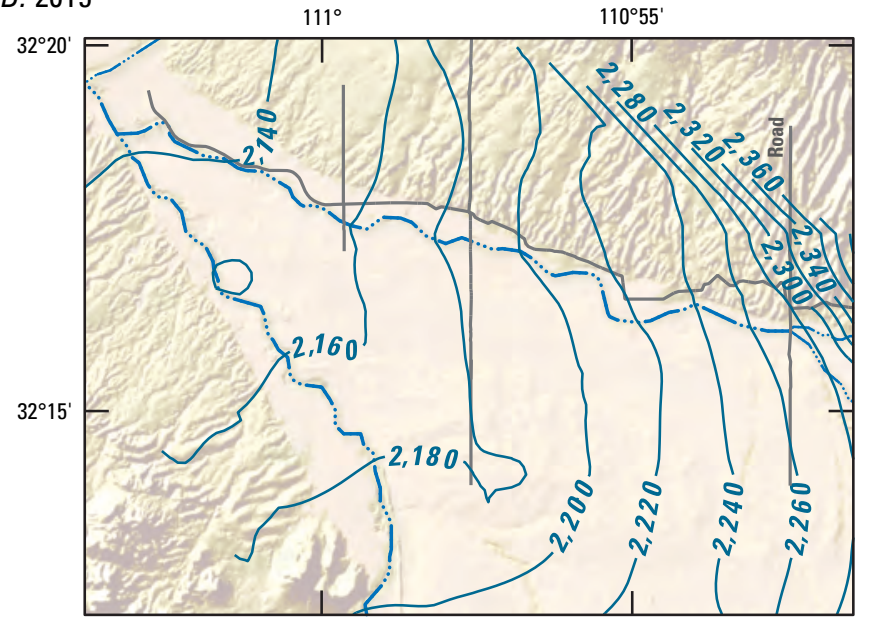

D. 2050

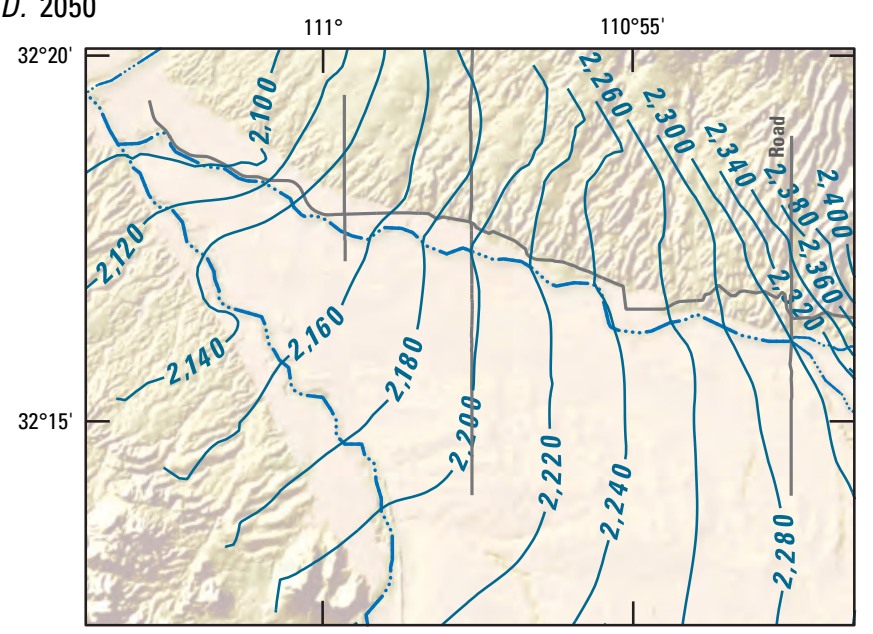

F. 2225
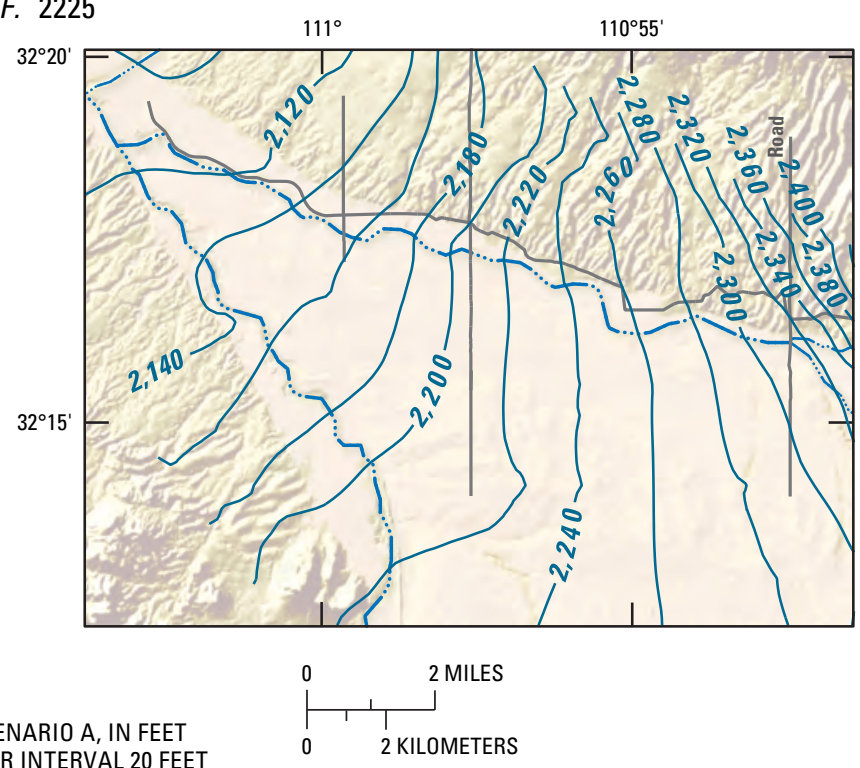

Figure 16. Water-level altitude for scenario $A$ in the local model for selected times, Rillito Creek, Arizona. $A, 2004 ; B, 2015 ; C, 2025$; $D, 2050 ; E, 2100 ; F, 2225$. 
Line segment 2.- The hydraulic gradient of the regional aquifer near line segment 2 is to the northwest, causing the net total flux past line segment 2 to be northwestward during the entire transient simulation; however, there is a decline in flux from 1,230 acre-ft/yr in 2004 to about 335 acre-ft/yr in 2025 (fig. 12). The decline in flux predominantly comes from a reduction in flow from layers 1 and 2 . The relative contribution of ground-water flux for each layer varies with time; however, layer 2 provides most of the flux across line segment 2. After 2027, layer 1 provides the least amount of flux at a rate less than 60 acre-ft/yr.

\section{Storage}

The component of ground water going into storage for all model layers during the simulation for scenario A rapidly changes from the end of 2004 to 2025 owing to changing pumping rates (fig. 13). The initial decrease in storage from 2004 to 2006 is due to increases in pumpage during the same time period. A large positive shift in storage occurs in 2007 owing to a reduction of ground-water pumpage. Subsequent forecasted pumpage increases from 2008 to 2025 (fig. 9) cause a decline of ground-water storage. The component of ground water going into storage continues to decline gradually until 2149 when storage changes become slightly negative and there is a small net loss of storage to the ground-water system.

\section{Evapotranspiration}

The rate of shallow ground-water discharge as ET during scenario A is constant at 191 acre-ft/yr (fig. 14). Scenario A does not result in a change in ET during the period of simulation because water levels near riparian areas do not change within the upper $25 \mathrm{ft}$ of the subsurface. A constant 141 acre-ft/yr of ET, or 74 percent of the total ET from the local model, occurs from a zone of cells surrounding Rillito Creek.

\section{Scenarios B, C, and D-Increased Recharge Rates, 2005-2225}

Most of the increased water added to the ground-water system in scenarios B, C, and D, relative to scenario A, can be accounted for by ground-water flux southward past line segment 1, ground-water flux northwestward past line segment 2, increased storage in the zone of cells surrounding Rillito Creek, or as increased ground-water discharge as ET in the zone of cells surrounding Rillito Creek. The effects of recharge scenarios B, C, and D on water levels, ground-water flux, storage, and ET are examined by describing differences in simulated hydrographs, water-level altitude contours, ground-water fluxes, storage, and losses to ET relative to scenario A. All water-level comparisons are made for model layer 2. Ground-water fluxes are shown as composite totals for all layers. Storage and ET changes are shown for a zone of cells that bound Rillito Creek. All comparisons begin in 2005, when recharge rates are changed, and extend to 2225.

\section{Water Levels}

Recharge in scenario B exceeds recharge in scenario A by about 9,500 acre-ft/yr (fig. 9). Simulated water levels rise to within about $50 \mathrm{ft}$ of predevelopment conditions near the Central Well Field and rise by as much as $86 \mathrm{ft}$ by 2225 relative to altitudes from scenario A (figs. 17, 18, and 19). These rises continue throughout the transient simulation; the rate of rise is about $0.1 \mathrm{ft} / \mathrm{yr}$ between 2224 and 2225 for most cells, indicating the differences would likely continue to increase if the simulations were extended beyond 2225. As of 2225, water-level rises beneath Rillito Creek range from about $53 \mathrm{ft}$ in the upper reach near Craycroft Road to $86 \mathrm{ft}$ near First Avenue relative to scenario A. Water-level rises for cells within the Central Well Field range from about 60 to $80 \mathrm{ft}$. More than half of the rises occur by 2050; at least 95 percent of the rises occur by 2188 .

Recharge in scenario $\mathrm{C}$ exceeds recharge in scenario $\mathrm{A}$, by about 16,700 acre-ft/yr (fig. 9). Simulated water levels rise to within a few feet of predevelopment conditions and rise as much as $102 \mathrm{ft}$ by 2225 relative to scenario A (figs. 17, 18, and 20). The rate of water-level rise for scenario $C$ is greater than that for scenario $\mathrm{B}$, but unlike scenario $\mathrm{B}$, scenario $\mathrm{C}$ water levels nearly stabilize, indicating only minimal waterlevel rises would occur beyond 2225. At the end of the transient simulation, water levels beneath Rillito Creek rise relative to scenario A and range from about $71 \mathrm{ft}$ in the upper reach near Craycroft Road to $102 \mathrm{ft}$ near La Cañada Avenue. Water-level rises for cells within the Central Well Field range from about 80 to $95 \mathrm{ft}$. More than half of the rises occur by 2036; at least 95 percent of the rises occur by 2100 .

Scenario D results in simulated water-level altitude increases of as much as $131 \mathrm{ft}$ relative to scenario A (figs. 17, 18, and 21). The water-level response associated with scenario D, however, differs from that in other scenarios because of a varying recharge rate used in scenario D. Initially, recharge occurs at a rate of 60,000 acre-ft/yr (an increase of about 55,000 acre-ft/yr relative to scenario A); however, this recharge rate results in water-level rises beneath Rillito Creek that reach land surface. As a result, the aquifer can no longer accept recharge, and surface water is transported downstream. Rising water levels beneath Rillito Creek cause recharge to be rejected after 2020. Recharge rates begin to decline in 2021 and settle at a rate of about 34,000 acre-ft/yr (an increase of about 29,000 acre-ft/yr relative to scenario A) by 2120. A long-term recharge rate of 34,000 acre-ft per year or greater, therefore, is likely to result in water levels that reach land surface and cause rejected recharge. At the end of the transient simulation in 2225, water levels beneath Rillito Creek stabilize; water-level rises relative to scenario A range from about $97 \mathrm{ft}$ in the upper reach near Craycroft Road to $131 \mathrm{ft}$ near La Cañada Avenue. Water-level rises for cells within the Central Well Field range from about 96 to $109 \mathrm{ft}$. More than half of the rises occur by 2018; at least 95 percent of the rises occur by 2041. The high water levels associated with scenario D could pose environmental issues owing to the presence of near-surface contaminant sources, such as landfills near and adjacent to Rillito Creek. 


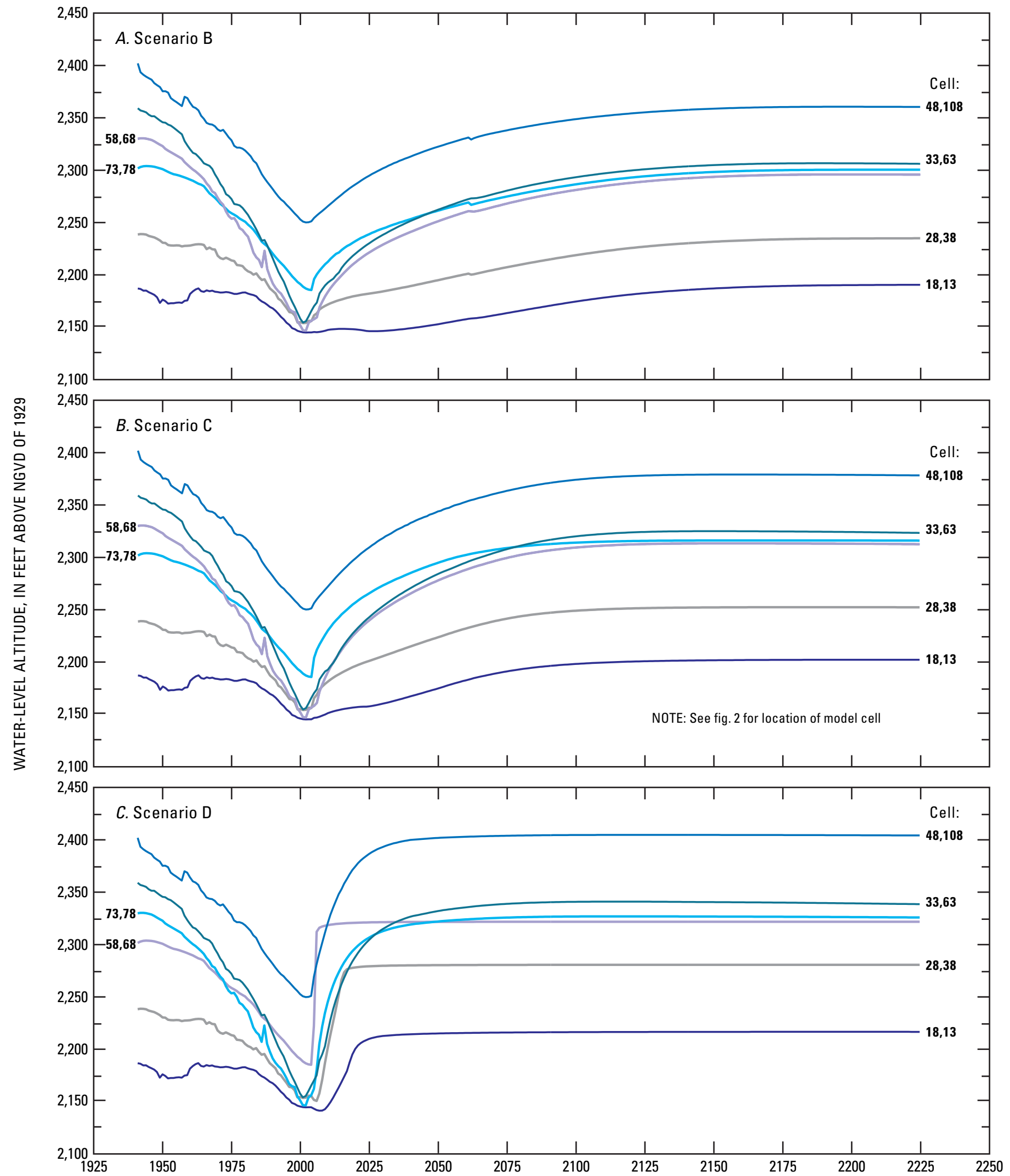

Figure 17. Water-level altitude for each scenario for cells in the local model, 1940-2225, Rillito Creek, Arizona. $A$, Scenario B; $B$, Scenario C; $C$, Scenario D. 


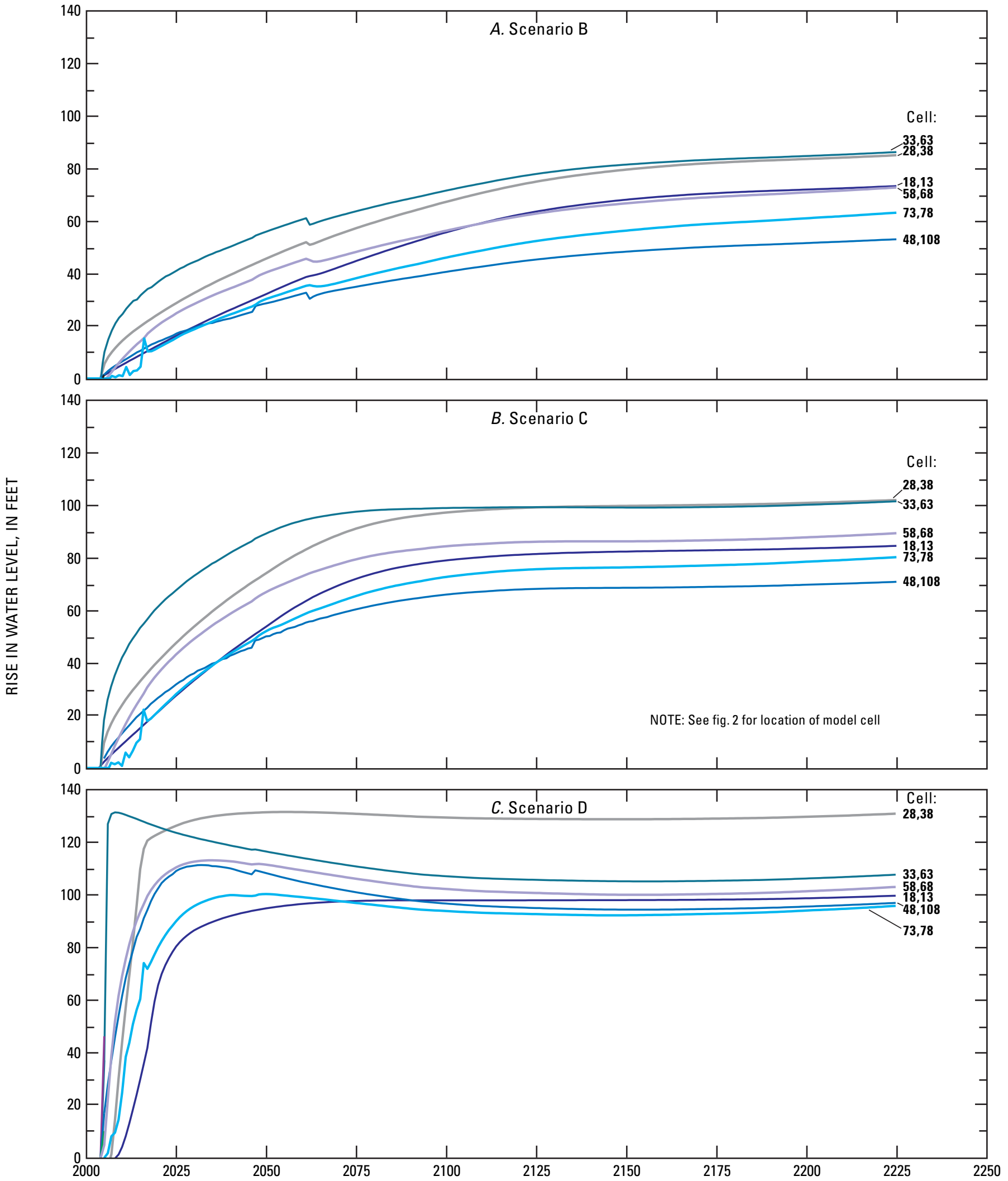

Figure 18. Rise in water level for each scenario relative to scenario $A$ for selected cells in the local model, 2000-2225, Rillito Creek, Arizona. A, Scenario B; $B$, Scenario $C$; $C$, Scenario D. 
A. 2015

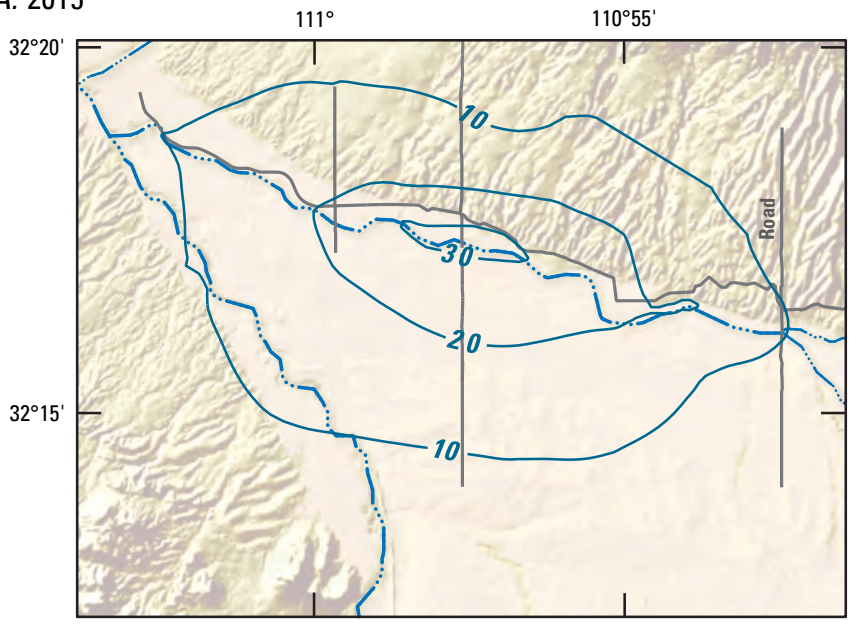

C. 2050

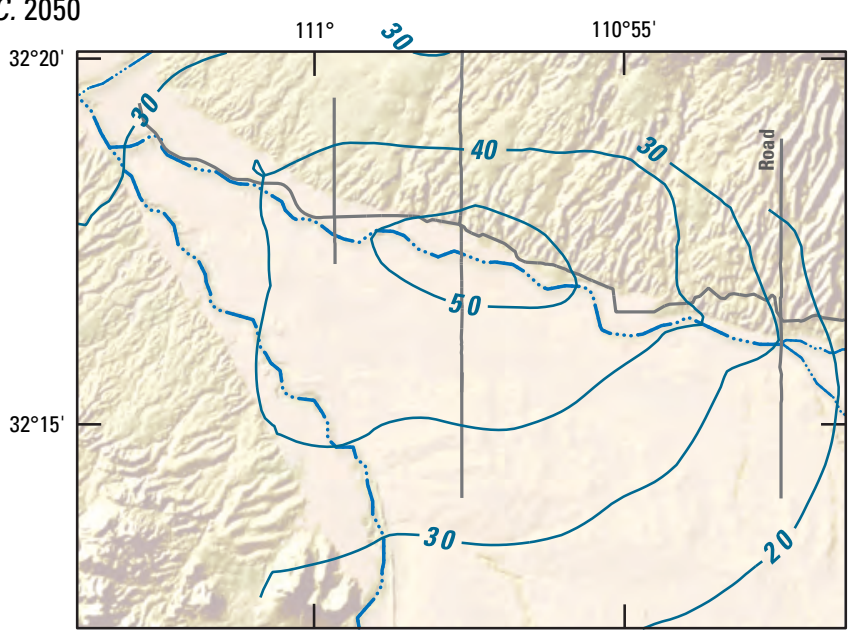

\section{E. 2150}

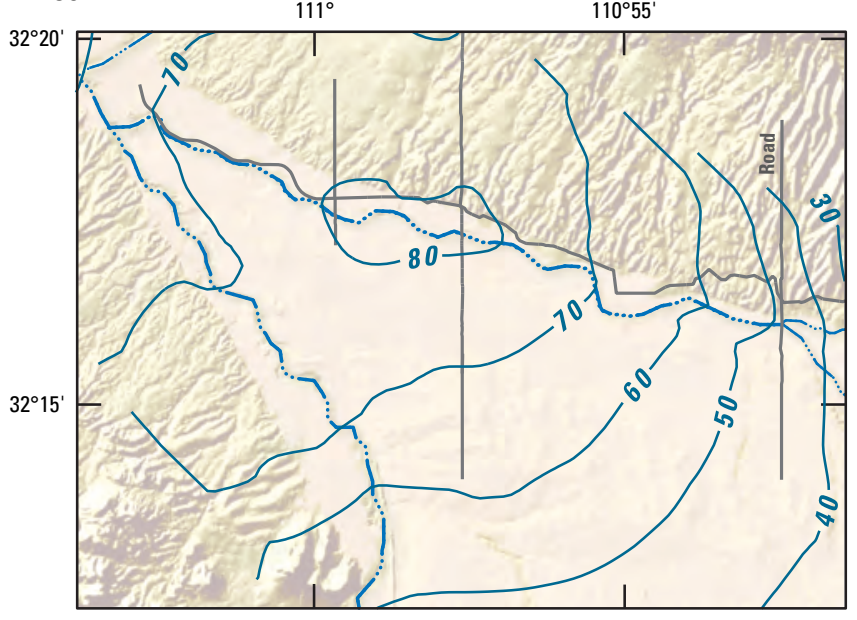

EXPLANATION $-50-$ RISE IN WATER LEVEL, IN FEET.
CONTOUR INTERVAL 10 FEET.
B. 2025

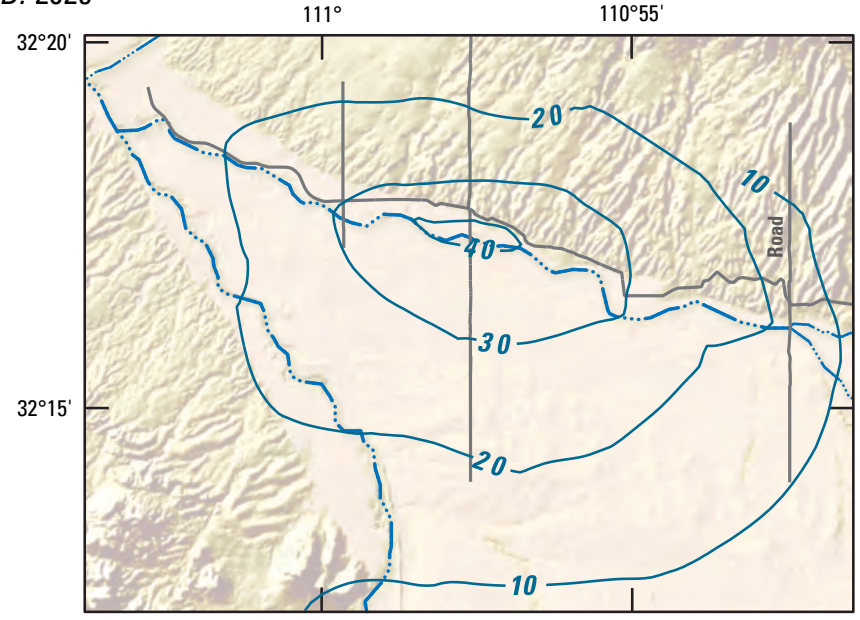

D. 2100

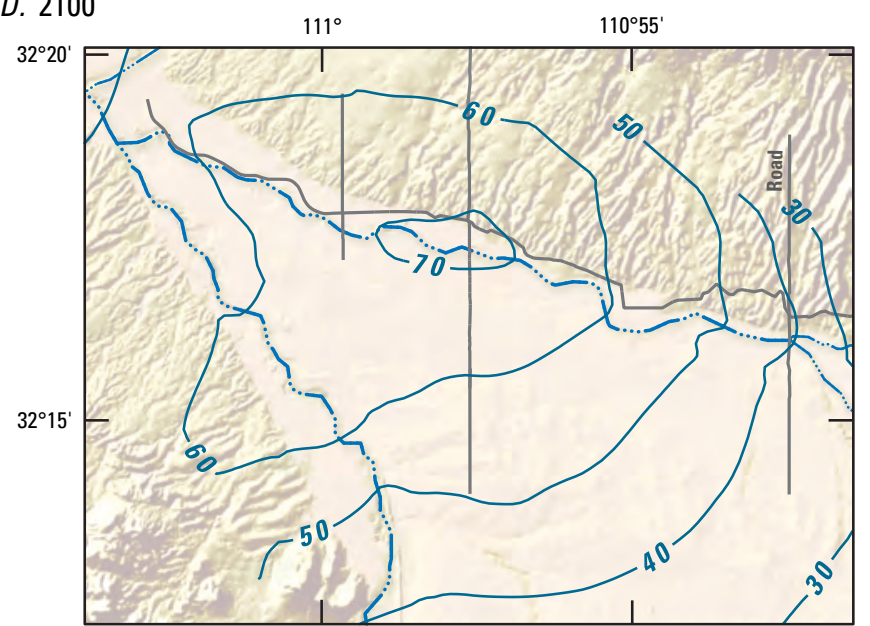

F. 2225

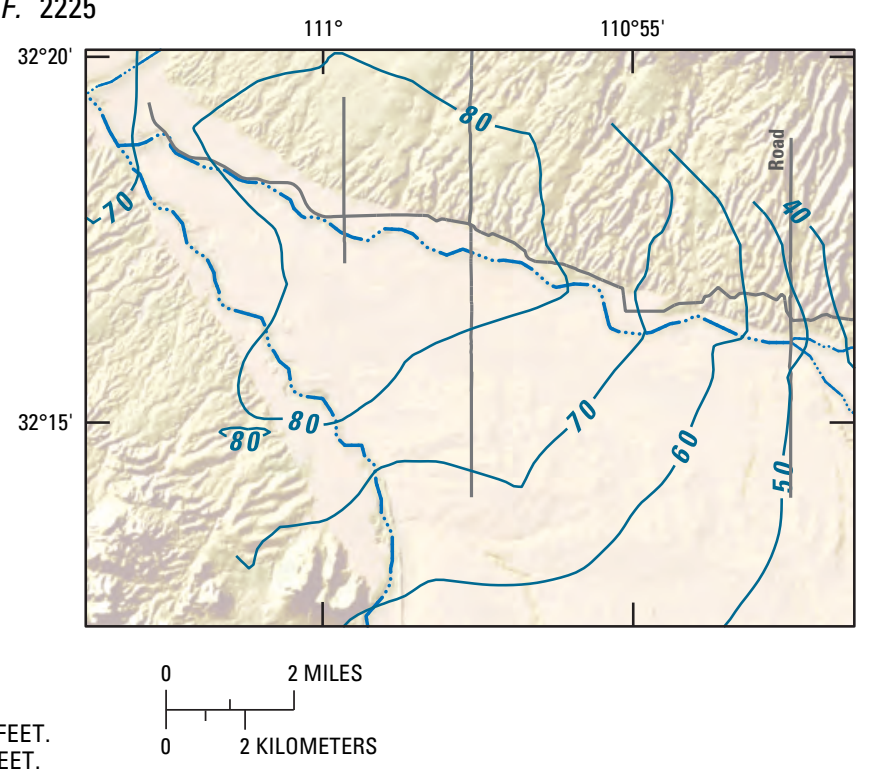

Figure 19. Rises in water level for scenario $B$ relative to scenario $A$ within the local model for selected times, Rillito Creek, Arizona. $A, 2015 ; B, 2025 ; C, 2050 ; D, 2100 ; E, 2150 ; F, 2225$. 
A. 2015

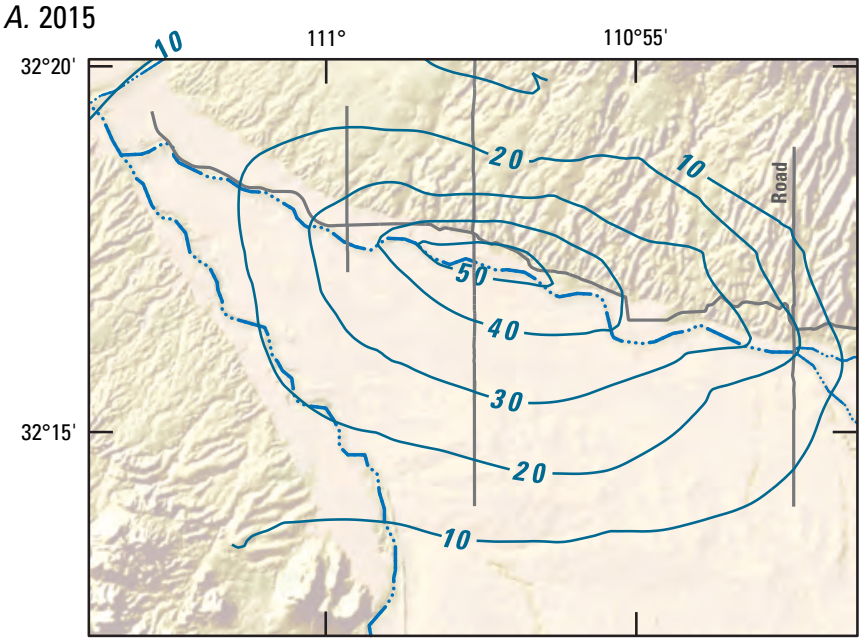

C. 2050

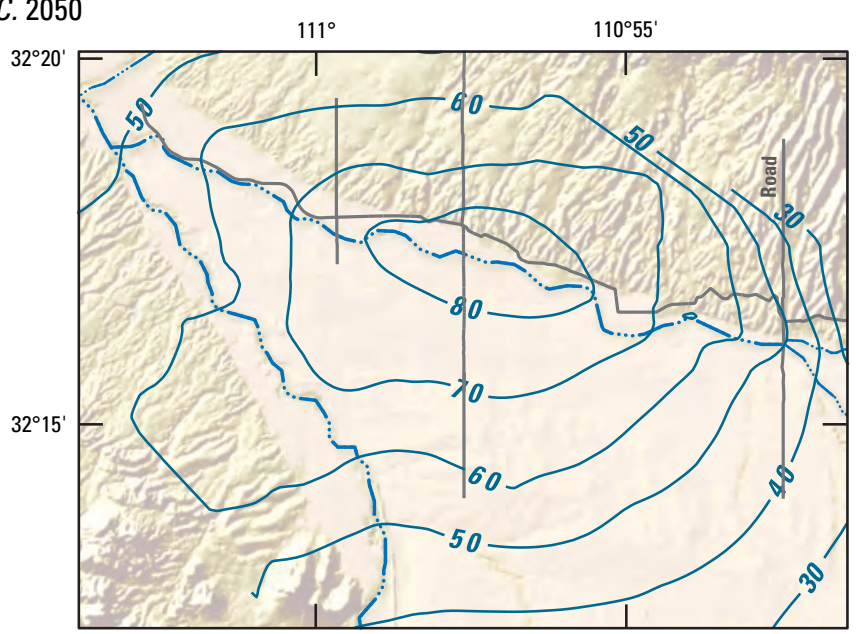

\section{E. 2150}

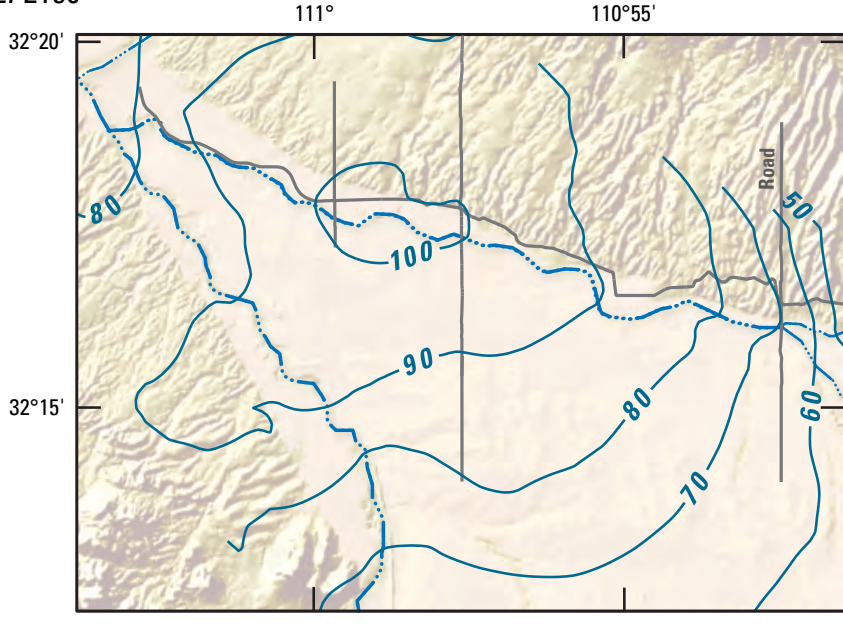

EXPLANATION

— 80 - RISE IN WATER LEVEL, IN FEET. CONTOUR INTERVAL 10 FEET.

\section{B. 2025}

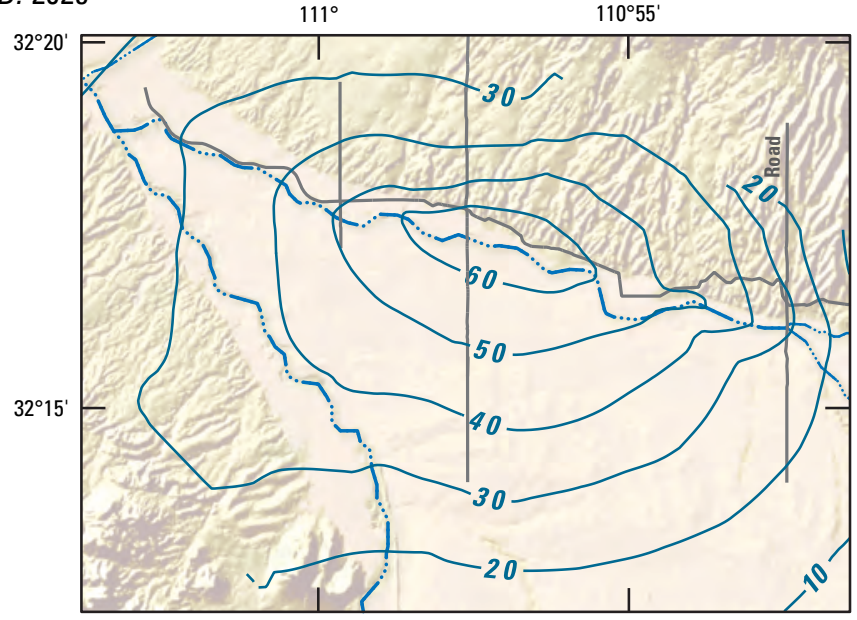

D. 2100

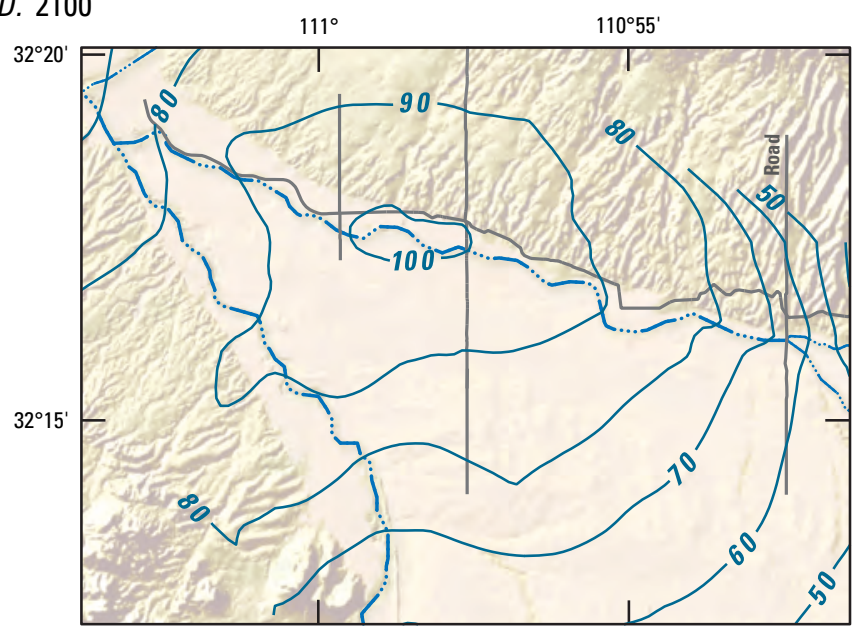

F. 2225

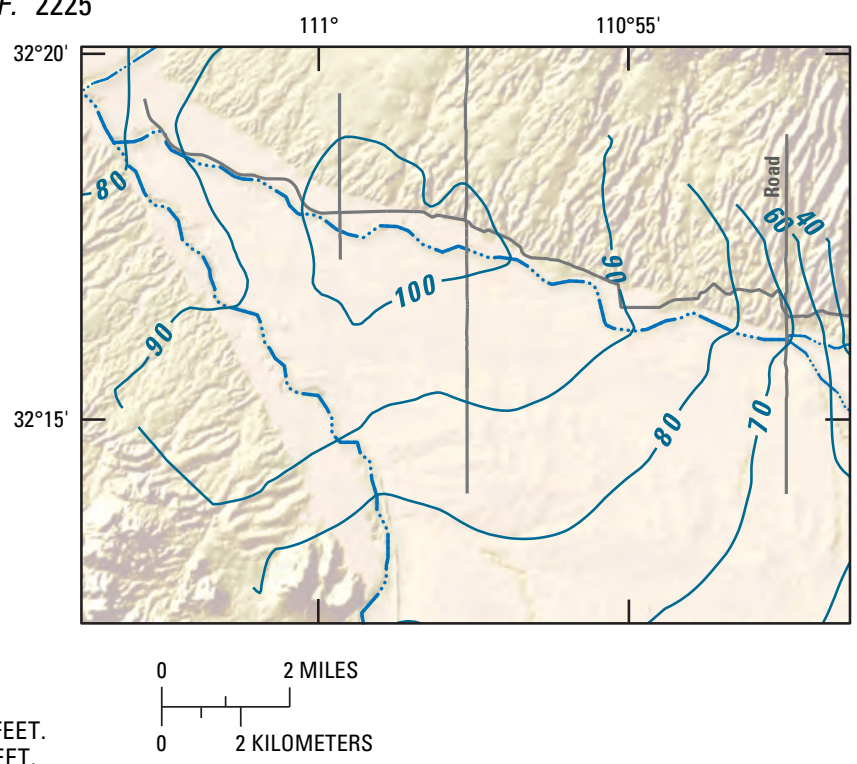

Figure 20. Rises in water level for scenario $C$ relative to scenario $A$ within the local model for selected times, Rillito Creek, Arizona. $A, 2015 ; B, 2025 ; C, 2050 ; D, 2100 ; E, 2150 ; F, 2225$. 
A. 2015

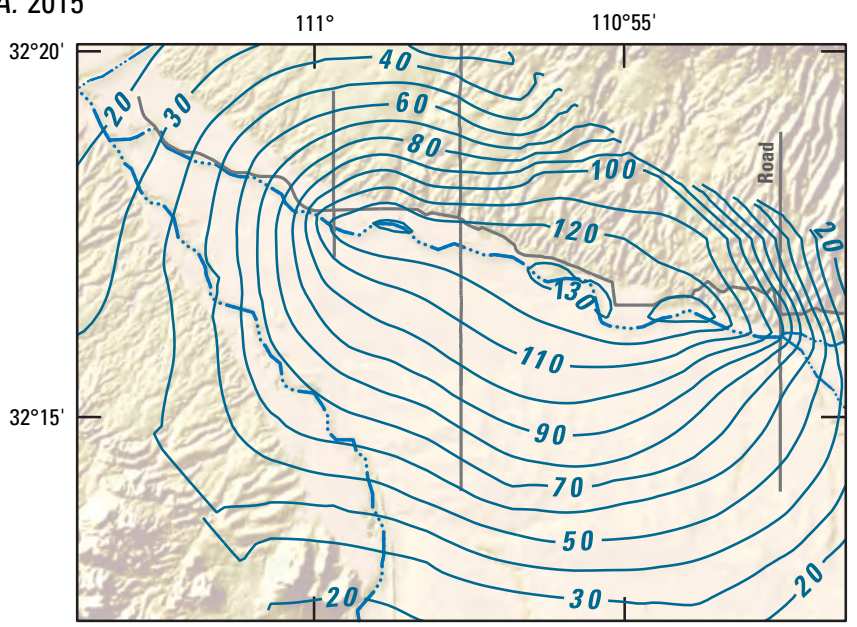

C. 2050

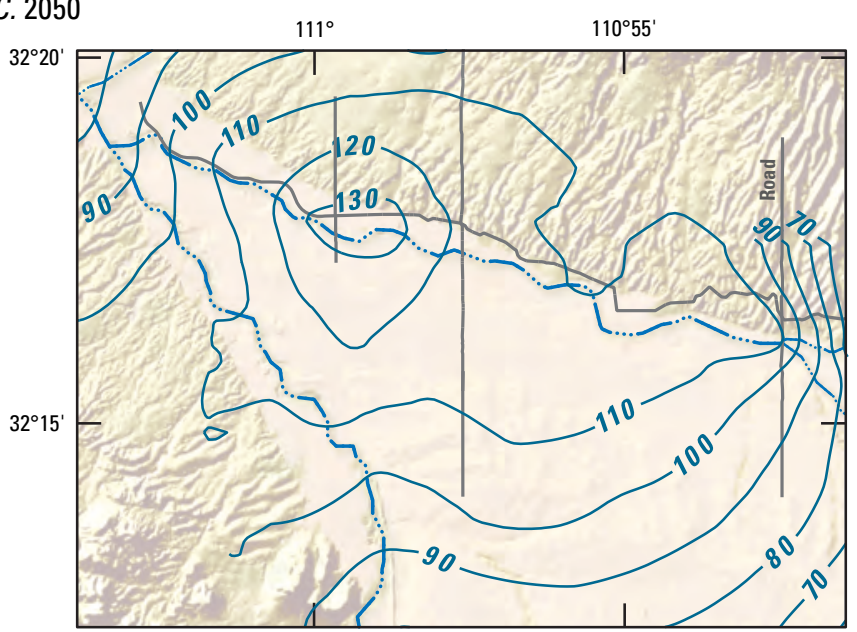

\section{E. 2150}

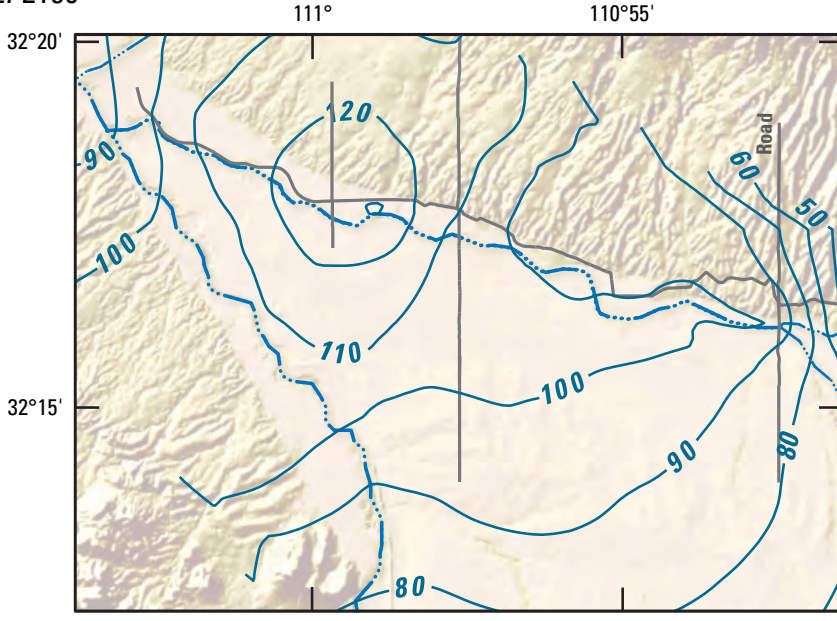

EXPLANATION $-90-$ RISE IN WATER LEVEL, IN FEET.
CONTOUR INTERVAL 10 FEET.
B. 2025

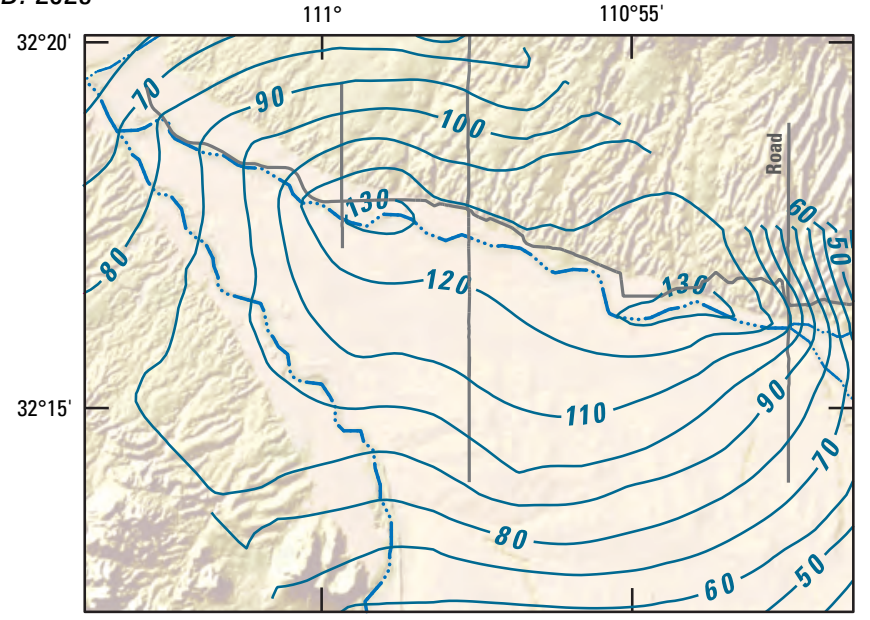

D. 2100

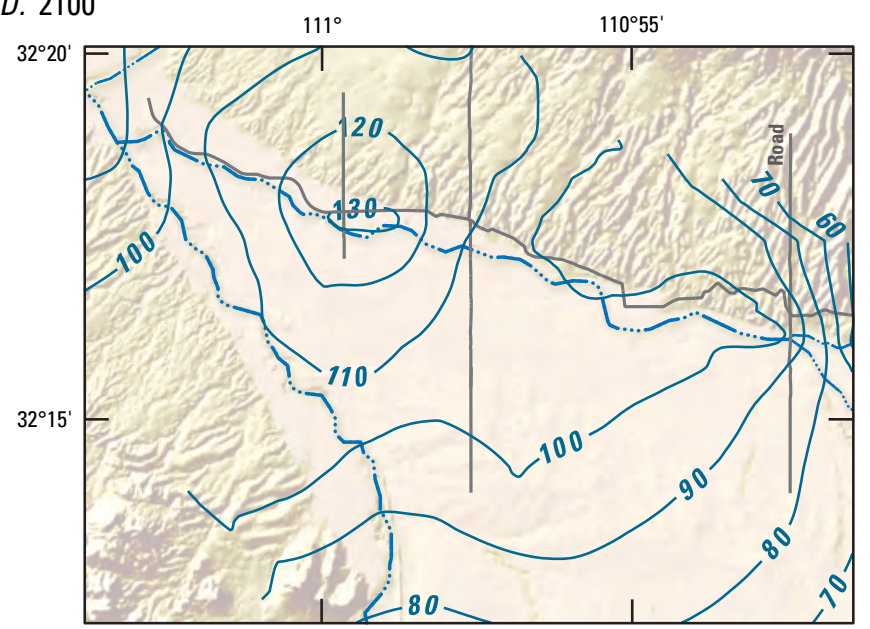

F. 2225

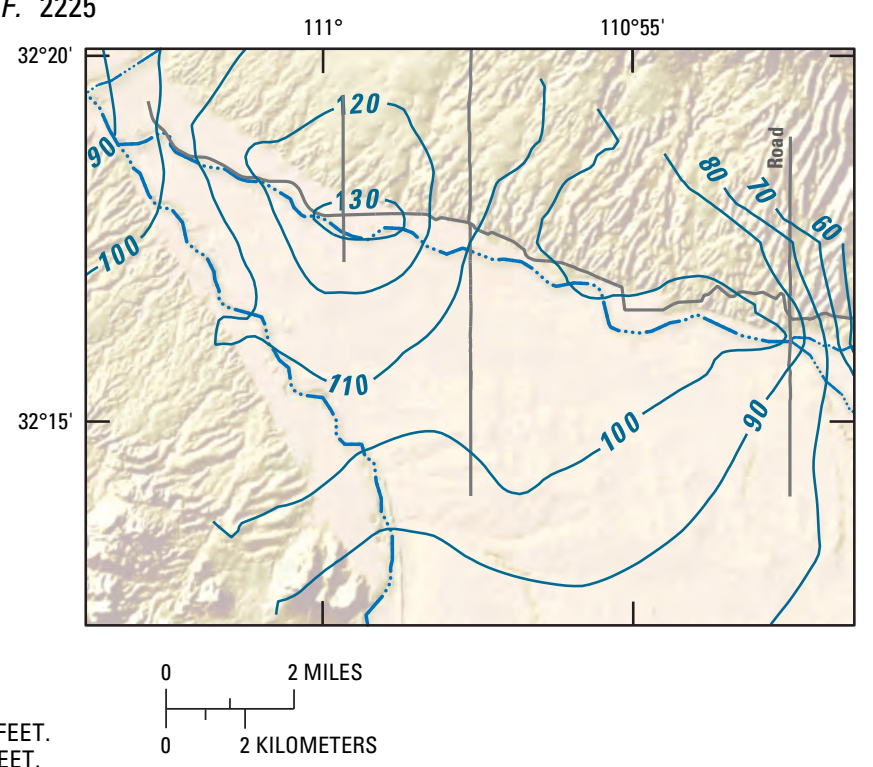

Figure 21. Rises in water level for scenario $D$ relative to scenario $A$ within the local model for selected times, Rillito Creek, Arizona. $A, 2015 ; B, 2025 ; C, 2050 ; D, 2100 ; E, 2150 ; F, 2225$. 


\section{Ground-Water Flux}

Scenario B results in long-term increases of about 3,300 acre-ft/yr in ground-water flux southward past line segment 1 (fig. 11) relative to scenario A. The increase in flux occurs as soon as the recharge scenario starts, and it reaches a maximum in 2010 at 4,500 acre-ft/yr. After 2010, the rate of southward flux decreases owing to a decrease in hydraulic gradient to the south. By 2225, the increase in the southward flux tapers to about 3,300 acre-ft/yr.

Scenario B also results in long-term increases of about 3,100 acre-ft/yr in ground-water flux northwestward past line segment 2, (fig. 12) relative to scenario A. Initially, the increase is small; however, the flux gradually increases, reaching a maximum of 3,100 acre-ft/yr in 2225. The increase in flux northwestward is due to an increase in hydraulic gradient to the northwest.

A maximum of about 47 percent of the added recharge in scenario B flows southward across line segment 1. The maximum flux occurs in year 2016, and the amount of water flowing southward gradually decreases to about 35 percent of the increased recharge by 2150 . Southward flux continues to decline until the end of the transient simulation. The percentage of increased recharge that flows northwestward past line segment 2 is low at the onset of the recharge scenario but gradually increases to about 31 percent in 2225 and continues to increase at the end of the transient simulation.

Scenario $C$ results in long-term increases of about 4,840 acre-ft/yr in ground-water flux southward past line segment 1 (fig. 11), relative to scenario A. The increase in flux occurs as soon as the recharge scenario starts and reaches a maximum of 8,000 acre-ft/yr in 2015. After 2015, the rate of southward flux decreases owing to a decrease in hydraulic gradient to the south, and by 2225 , the long-term southward flux tapers to about 4,840 acre-ft/yr (fig. 11).

Scenario $\mathrm{C}$ also results in long-term increases of about 3,900 acre-ft/yr in ground-water flux northwestward past line segment 2 (fig. 12), relative to scenario A. Initially, the increase is small; however, the flux reaches a maximum of about 3,960 acre-ft/yr in 2131. The increase in flux northwestward is due to an increase in hydraulic gradient to the northwest.

A maximum of about 48 percent of the added recharge in scenario $\mathrm{C}$ flows southward across line segment 1 . The amount of water flowing southward gradually decreases to about 29 percent of the increased recharge. The percentage of increased recharge that flows northwestward past line segment 2 is low at the onset of the recharge scenario but gradually increases to about 25 percent in 2118 and continues to show small increases until the end of the transient simulation.
The long-term increase in recharge for scenario $\mathrm{D}$ relative to scenario A is 29,000 acre-ft/yr; however, initial increases are about 55,000 acre-ft/yr. Scenario D results in long-term increases of about 7,500 acre-ft/yr in ground-water flux southward past line segment 1 (fig. 11), relative to scenario A. The changing recharge rate of scenario $\mathrm{D}$ causes the initial increase in flux to reach a maximum of about 29,000 acre$\mathrm{ft} / \mathrm{yr}$ in 2013. After 2013, the rate of southward flux decreases owing to a decrease in hydraulic gradient to the south and to a reduction in recharge after 2020. By 2225, the southward flux has tapered to about 7,500 acre-ft/yr, which is about 26 percent of the increase in recharge.

Scenario D also results in long-term increases of about 6,000 acre-ft/yr in ground-water flux northwestward past line segment 2 (fig. 12), relative to scenario A. Initially (2005-2007), the increase is small; however, the flux increases, reaching a maximum relative to scenario $\mathrm{A}$ of $6,980 \mathrm{acre}-\mathrm{ft} / \mathrm{yr}$ in 2019. The increase in flux northwestward is due to an increase in hydraulic gradient to the northwest. There is a gradual decrease in northwestward flux after 2030 owing to the reduced recharge rate. About 21 percent of the long-term increased recharge applied in scenario D flows northwestward past line segment 2.

\section{Storage}

Storage change related to each recharge scenario is calculated by summing the storage budget terms for a zone of cells that bound Rillito Creek (fig. 2). The program Zonebudget (Harbaugh, 1990) was used to calculate the budget terms for this zone.

The largest storage changes for scenarios B, C, and D relative to scenario A occur early in the simulations, and by 2015, the changes begin to decrease for all scenarios (fig. 13). Change in storage accounts for more than 50 percent of the newly added recharge early in the recharge scenario but declines to near zero percent by the end of the simulation (fig. 13).

\section{Evapotranspiration}

Removal of shallow ground water through ET varies for each scenario (fig. 14). Increases in ground-water ET rates are a function of depth to water and areal distribution of the shallow ground water. ET rates increase the earliest and the most for scenario D and the latest and the least for scenario B. The ET rate for scenario A is $191 \mathrm{acre}-\mathrm{ft} / \mathrm{yr}$, and there is no rate change between 2004 and 2225. Losses to ET primarily occur in two zones of cells-one zone surrounding the Santa Cruz River and the other surrounding Rillito Creek. The fraction of the total ET that occurs within the zone of cells surrounding Rillito Creek varies among the scenarios (table 2). 
Table 2. Evapotranspiration within local ground-water flow model for various scenarios, Rillito Creek, Arizona

\begin{tabular}{crrc}
\hline Scenario & $\begin{array}{c}\text { Total for all } \\
\text { cells within } \\
\text { the local } \\
\text { model }\end{array}$ & $\begin{array}{c}\text { Cells along } \\
\text { Rillito Creek }\end{array}$ & $\begin{array}{c}\text { Percentage of } \\
\text { evapotranspiration } \\
\text { along Rillito Creek }\end{array}$ \\
\hline A & 191 & 141 & 74 \\
B & 1,397 & 454 & 32 \\
C & 7,324 & 4,260 & 58 \\
D & 13,355 & 12,100 & 91 \\
\hline
\end{tabular}

Relative to the amount of added recharge for each scenario, increased ET accounts for 3, 25 and 41 percent for scenarios $\mathrm{B}, \mathrm{C}$, and D, respectively (fig. 14).

\section{Limitations of the Local Flow Model}

The local-model data sets are constructed with the program MODTMR by using information contained in the regional-model data sets. The TAMA model data sets are grid dependent; that is each cell is associated with specific properties. All local cells overlying TAMA model cells contain properties consistent with those of the TAMA model cells. Location information is not contained in grid-dependent TAMA models to precisely locate sources and sinks in the local-model grid.

The accuracy of the local model is dependent on the accuracy of the TAMA model. All finite difference flow models, including the TAMA model, are numerical simplifications of a complex natural system. The numerical model is based on a conceptualization of the natural surface- and ground-water flow system. Inherent in the conceptualization is the assumption that all sources of flow and stress on the natural system are represented in the numerical model and are accurately known. In most cases, however, all sources of flow and stress on the natural system can never be fully accounted.

One important simplification of the TAMA and local models is that layer 1 is represented by the hydraulic properties of the Fort Lowell Formation. This simplification is probably adequate for most uses of the flow model. When recharge rates along Rillito Creek are significantly high, however, the water level rises to near the land surface and into the stream-channel deposits. Hoffmann and others (2002) show that the hydraulic conductivity of the stream-channel deposits, which are generally about $40 \mathrm{ft}$ thick, is about twice that of the underlying basin-fill deposits. A model simulation in which an additional layer is used to represent the streamchannel deposits would result in somewhat differing water levels, ground-water fluxes, and storage changes. The larger hydraulic conductivity of the stream-channel deposits would likely result in lowered water levels. In addition, owing to the northwestward orientation of the Rillito Creek stream channel, ground-water fluxes northwestward are likely to increase relative to fluxes southward if a larger conductivity layer is used for the shallow stream-channel deposits.

Another important simplification of the TAMA and local models is that all routed water either recharges to the aquifer or flows out of the stream reach. The full amount of water recharges instantaneously and no time is needed for water to flow through the unsaturated zone. Furthermore, no water is lost to storage in the unsaturated zone or to ET prior to recharge. Consequently, in order for recharge to occur at the rates discussed in the various recharge simulations, the amount of water has to increase to account for actual storage and ET loss. In cases where there is no rejected recharge, the actual recharge rates would be less than the specified discharge to the stream if ET in the unsaturated zone was accounted for in the model. The recharge rates used in the simulations are thus considered maximum recharge rates.

Another simplification of the model is that streambed conductance is assumed to be constant during each stress period. Streambed conductance, which is a function of vertical hydraulic conductivity of the streambed, is likely to change during and between streamflow or recharge events. Bailey (2002) showed variations of vertical hydraulic conductivity of as much as four orders of magnitude during or between streamflows in Rillito Creek.

Simulation of ET was made on the basis of vegetation type and density observed on aerial photographs taken in 1936 and 1941. An extinction depth of $25 \mathrm{ft}$ was assigned on the basis of rooting depths for mesquite and cottonwood. These phreatophytes, although still in existence within the study area, are likely to have a reduced density owing to human developments. A reduced ET rate due to decreased vegetation density is not simulated in the TAMA or local model. A shallower rooting depth appropriate for current vegetation also was not used. In addition, the surface area used to estimate the location of phreatophytes and calculate ET rates is made on the basis of the TAMA model cell assignments. Each TAMA model cell is $2,680 \mathrm{ft}$ on a side and comprises 25 local-model cells. Given that Rillito Creek is about $300 \mathrm{ft}$ wide, the surface area represented by cells with ET assignments is larger than the actual surface area of Rillito Creek. Cell assignments between the TAMA and local models were made to maintain consistency between water-budget components in the two models.

The local model was not calibrated, but calibration of the TAMA model was assumed to apply in general to the local model. The TAMA model used to create boundary conditions for the local model, however, simulates recharge with the Stream Package for cells coincident with Rillito Creek. The period of calibration for the TAMA model extended from 1940 to 1999.

Forcasted simulations of the ADWR model through 2025 are based on a predicted pumpage distribution and a constant recharge rate. Subsequent forecasted simulations extended to 2225 maintain the predicted pumpage distribution of 2025 and assumed a constant recharge rate for each simulation. A con- 
stant pumpage distribution from 2025 to 2225 is improbable, as is a constant recharge rate.

Given the simplifications and associated limitations of the model, results presented here cannot be considered predictive. Rather, these results are interpretive and are best suited for evaluating system responses to stress.

\section{Summary and Conclusions}

The amount of water currently recharging the aquifers within the Tucson area is insufficient to meet current and projected future demands on the ground-water flow system. Currently, resultant ground-water deficits are manifested in waterlevel declines of more than $200 \mathrm{ft}$ since the middle of the twentieth century. These declines are largest where groundwater withdrawals are highest-generally in association with Tucson's Central Well Field. To help mitigate the deficit and associated water-level declines, an in-stream recharge facility has been proposed in Rillito Creek, an ephemeral stream on the northern side of Tucson. Numerical simulations of a local ground-water flow model were used to evaluate mitigating effects on ground-water deficits and water-level declines for various recharge scenarios within Rillito Creek.

The local model was nested within a regional (TAMA) ground-water flow model to provide boundary conditions. The local flow model was centered approximately over Rillito Creek and Tucson's Central Well Field. The purpose of this investigation was to evaluate recharge scenarios related to the introduction of CAP water to Rillito Creek; therefore, recharge was simulated in the local model by using the Stream Package. Applying recharge by using the Stream Package had the advantage over applying recharge by using the Recharge Package because recharge in the former is calculated on the basis of head differences between the stream and the aquifer and a streambed-conductance term. In addition, the Stream Package enabled a variety of recharge scenarios to be evaluated by using differing streamflow values along Rillito Creek. Although the amount of recharge applied by using the two packages was the same, the distribution of recharge was slightly different along Rillito Creek. Simulations that included the Stream Package resulted in less recharge in the upper reach and more recharge in the middle reach than simulations that included the Recharge Package. The recharge distribution simulated by the Stream Package is in better agreement with results from seepage measurements and microgravity surveys than the distribution simulated by the Recharge Package. The Stream Package terms also can be justified on the basis of textural and geophysical data collected along the creek. The different recharge distributions resulted in only slightly different water levels. The streamflow values routed with the Stream Package for the recharge scenarios included 5,000, 14,500, 21,000, and 60,000 acre-ft/yr. A longterm average recharge rate used in the TAMA model for cells underlying Rillito Creek was represented by 5,000 acre-ft/yr, and 60,000 acre-ft/yr represented the maximum amount of CAP water available for artificial recharge along Rillito Creek.

Simulated steady-state and transient water-level altitudes in the TAMA and local models are in good agreement. This agreement provided confidence that the local model represents the TAMA model and thus could be used to evaluate forecast simulations based on a variety of recharge scenarios.

Simulated water levels for recharge scenarios B, C, and $\mathrm{D}$ rose relative to water levels for scenario A. Water levels throughout the local modeled area rose by as much as $131 \mathrm{ft}$. Most of the increased water added to the ground-water system in the scenarios was accounted for by a combination of increased storage near Rillito Creek, ground-water flux southward, ground-water flux northwestward, and increased discharge as ET along Rillito Creek. The percentage of newly added water attributed to storage change is large relative to the percentage attributed to changes in ground-water flux and ET at the onset of each scenario; however, the change in storage become smaller throughout the simulation, and the long-term storage change is minimal.

For scenario B, which increased the recharge along Rillito Creek by about 9,500 acre-ft/yr, simulated water-level rises beneath Rillito Creek ranged from about 53 to $86 \mathrm{ft}$ relative to scenario A. Water-level rises for cells within Tucson's Central Well Field ranged from about 60 to $80 \mathrm{ft}$. More than half of the rises occurred by 2050; at least 95 percent of the rises occurred by 2188. Long-term ground-water flux to the south and northwest increased by about 3,300 and 3,100 acre$\mathrm{ft} / \mathrm{yr}$, respectively. About 35 and 31 percent of the long-term increased recharge flowed southward and northwestward, respectively. ET along Rillito Creek increased from 191 to 454 acre-ft/yr. The increase in ET represents about 3 percent of the increased recharge.

For scenario $\mathrm{C}$, which increased the recharge along Rillito Creek by about 16,700 acre-ft/yr, simulated waterlevel rises beneath Rillito Creek ranged from about 71 to $102 \mathrm{ft}$ relative to scenario A. Water-level rises for cells within Tucson's Central Well Field ranged from about 80 to $95 \mathrm{ft}$. More than half of the rises occurred by 2036; at least 95 percent of the rises occurred by 2100. Long-term ground-water flux to the south and northwest increased by about 4,840 and 3,900 acre-ft/yr, respectively. About 29 and 25 percent of the long-term increased recharge flowed southward and northwestward, respectively. ET increased from $141 \mathrm{acre}-\mathrm{ft} / \mathrm{yr}$ to about 4,260 acre-ft/yr along Rillito Creek. The increase in ET represents about 25 percent of the increased recharge.

Scenario D, which initially increased the recharge rate by about 55,000 acre-ft/yr relative to scenario A, resulted in simulated water levels that rose to land surface along Rillito Creek. This rise in water level resulted in rejected recharge. As the water table rose, the recharge rate continued to decline until a long-term rate of about 34,000 acre-ft/yr along Rillito Creek was sustained - an increase of about 29,000 acre-ft/yr relative to scenario A. Simulated long-term water-level rises beneath Rillito Creek ranged from about 97 to $131 \mathrm{ft}$, causing water levels to be near or at the land surface. Shallow water 
levels associated with this scenario could pose environmental problems owing to the presence of landfills adjacent to Rillito Creek. Water-level rises for cells within the Central Well Field ranged from about 96 to $109 \mathrm{ft}$. More than half of the waterlevel rises occurred by 2018; at least 95 percent of the waterlevel rises occurred by 2041. Long-term ground-water flux to the south and northwest increased by about 7,500 acre-ft/yr and 6,000 acre-ft/yr, respectively. About 26 and 21 percent of the long-term increased recharge flowed southward and northwestward, respectively. ET increased about 12,000 acre$\mathrm{ft} / \mathrm{yr}$ along Rillito Creek, or about 41 percent of the long-term increased recharge.

Results beyond 2025 are considered interpretive owing to the simplification of the model used for the scenarios presented. The longer-term analysis, therefore, is considered to be an interpretive-model application in which results represent possible long-term responses that are predicated on the most complete information currently available.

\section{References}

Anderson, S.R., 1987, Cenozoic stratigraphy and geologic history of the Tucson basin, Pima County, Arizona: U.S. Geological Survey Water-Resources Investigations Report 87-4190, 20 p.

Anderson, S.R., 1988, Potential for aquifer compaction, land subsidence, and earth fissures in the Tucson basin, Pima County, Arizona: U.S. Geological Survey Hydrologic Investigations Atlas HA-713, 3 sheets, scale 1:250,000.

Anderson, T.W., 1972, Electric-analog analysis of the hydrologic system, Tucson Basin, southeastern Arizona: U.S. Geological Survey Water-Supply Paper 1939-C, 34 p.

Anderson, T.W., Freethey, G.W., and Tucci, Patrick, 1990, Geohydrology and water resources of alluvial basins in south-central Arizona and parts of adjacent states: U.S. Geological Survey Open-File Report 89-378, 99 p.

Arizona Department of Water Resources, 2004, Water management, accessed June 15, 2004 at http://www.water. az.gov/WaterManagement/Content/AMAs/TucsonAMA/ default.htm

Bailey, M.A., 2002, Analysis of vertical hydraulic conductivity using heat as a tracer to estimate streambed infiltration in Rillito Creek, Tucson, Arizona: Tucson, University of Arizona, master's thesis, 158 p.

Burkham, D.E., 1970, Depletion of streamflow by infiltration in the main channels of the Tucson Basin, southeastern Arizona: U.S. Geological Survey Water-Supply Paper 1939-B, 36 p.
Davidson, E.S., 1973, Geohydrology and water resources of the Tucson Basin, Arizona: U.S. Geological Survey WaterSupply Paper 1939-E, 81 p.

Fenneman, N.M., 1931, Physiography of the western United States: New York, McGraw-Hill, 534 p.

Hanson, R.T., and Benedict, J.F., 1994, Simulation of groundwater flow and potential for land subsidence, Upper Santa Cruz Basin, Arizona: U.S. Geological Survey WaterResources Investigations Report 93-4196, 52 p.

Harbaugh, A.W., 1990, A computer program for calculating subregional water budgets using results from the U.S. Geological Survey modular three-dimensional finite-difference ground-water flow model: U.S. Geological Survey Open-File Report 90-392, 46 p.

Harbaugh, A.W., Banta, E.R., Hill, M.C., and McDonald, M.G., 2000, MODFLOW-2000, the U.S. Geological Survey modular ground-water model-User guide to modularization concepts and the ground-water flow process: U.S. Geological Survey Open-File Report 00-92, 121 p.

Hoffmann, J.P., Ripich, M.A, and Ellett, K.M., 2002, Characteristics of shallow deposits beneath Rillito Creek, Pima County, Arizona: U.S. Geological Survey WaterResources Investigations Report 01-4257, 51 p.

Leake, S.A., and Claar, D.V., 1999, Procedures and computer programs for telescopic mesh refinement using MODFLOW: U.S. Geological Survey Open-File Report 99-238, 53 p.

Matlock, W.G., and Davis, P.R., 1972, Groundwater in the Santa Cruz Valley, Arizona: University of Arizona Agricultural Experiment Station Technical Bulletin 194, 37 p.

McDonald, M.G., and Harbaugh, A.W., 1988, A modular three-dimensional finite-difference ground-water flow model: U.S. Geological Survey Techniques of WaterResources Investigations, book 6, Modeling Techniques, chap. A1, 586 p.

McDonald, M.G., and Harbaugh, A.W., 1996, User's documentation for MODFLOW-96, an update to the U.S. Geological Survey modular finite-difference groundwater flow model: U.S. Geological Survey Open-File Report 96-485 56 p.

Ozbilgin, M.M., and Dickerman, D.C., 1984, A modification of the finite-difference model for simulation of two dimensional ground-water flow to include surface-ground water relationships: U.S. Geological Survey WaterResources Investigations Report 83-4251, 98 p.

Pashley, E.F., Jr., 1966, Structure and stratigraphy of the central, northern, and eastern parts of the Tucson basin, Arizona: Tucson, University of Arizona, Ph.D. dissertation, 273 p. 
Pool, D.R., 1985, Aquifer geology of alluvial basins of Arizona, in Anderson T.W., and Johnson A.I., eds., Regional aquifer systems of the United States, southwest alluvial basins of Arizona: American Water Resources Association Monograph 7 p. 25-36.

Pool, D.R., and Schmidt, W., 1997, Measurement of groundwater storage change and specific yield using the temporal-gravity method near Rillito Creek, Tucson, Arizona: U.S. Geological Survey Water-Resources Investigations Report 97-4125, 30 p.

Prudic, D.E., 1989, Documentation of a computer program to simulate stream-aquifer relations using a modular, finite difference, ground-water flow model: U.S. Geological Survey Open-File Report 88-729, 113 p.

Reynolds, S.J., 1988, Geologic map of Arizona: Tucson, Arizona Geological Survey Map M, scale 1:1,000,000.
Travers, B.C., and Mock, P.A., 1984, Groundwater modeling study of the upper Santa Cruz basin and Avra Valley in Pima and Santa Cruz Counties, southeastern Arizona: Arizona Department of Water Resources, Hydrology Division, Unnumbered Modeling Report, 2 v., 65 p.

Tucson Water, 2000, Annual static water level basic data report, Tucson basin and Avra Valley Pima County, Arizona, 1997: City of Tucson, Tucson Water, Planning \& Engineering Division.

Water Resources Research Center, 1999, Water in the Tucson area-Seeking sustainability: Tucson, University of Arizona, College of Agriculture, $155 \mathrm{p}$.

White, F.M., ed., 1979, Fluid mechanics: New York, McGrawHill, 701 p. 
This page left blank intentionally. 
This page left blank intentionally. 


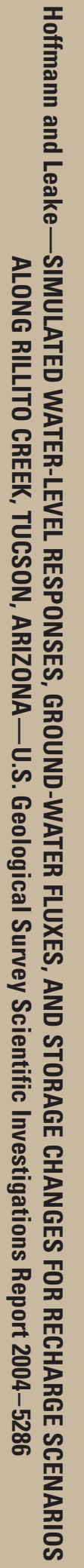

Printed on recycled paper 